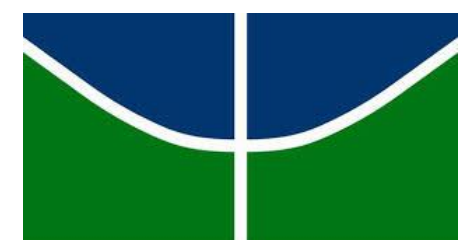

Universidade de Brasília

Instituto de Letras - IL

Departamento de Linguística, Português e Línguas Clássicas - LIP

Programa de Pós-Graduação em Linguística - PPGL

\title{
ESTUDO DE CASO SOBRE O DESENVOLVIMENTO DA CONSCIÊNCIA SINTÁTICA EM SALA DE AULA
}

Juliana Carolina Argenta Carlos Lopes da Silva.

Brasília, 


\title{
ESTUDO DE CASO SOBRE O DESENVOLVIMENTO DA CONSCIÊNCIA SINTÁTICA EM SALA DE AULA
}

\author{
Juliana Carolina Argenta Carlos Lopes da Silva
}

\author{
Dissertação apresentada como requisito \\ parcial para a obtenção do grau de mestre em \\ linguística no Programa de Pós-graduação em \\ Linguística da Universidade de Brasília, sob a \\ orientação da Professora Doutora Eloisa \\ Nascimento Silva Pilati.
}

Banca examinadora:

Profa. Dr. Eloisa Nascimento Silva Pilati (PPGL/UnB) - Presidente Prof. Dr. Marco Antonio Martins (UFRN) - Membro externo Profa. Dr. Rozana Reigota Naves (PPGL/UnB) - Membro interno Profa. Dr. Heloisa Maria Moreira Lima Salles (PPGL/UnB) - Suplente

Brasília,

2015. 


\section{Agradecimentos}

A Deus, por se fazer presente em todas as minhas epifanias.

Aos meus pais, pois ser motivo de orgulho para vocês é uma das minhas maiores motivações.

À minha orientadora Prof ${ }^{a}$. Dr ${ }^{a}$. Eloisa Pilati, por ser, dentre todos os que dizem acreditar no meu sucesso, uma das poucas pessoas que realmente trabalha comigo para que eu o alcance.

Aos meus colegas Camila, Jonathan e Manuela, por tornarem essa jornada muito mais divertida. 


\section{SUMÁRIO}

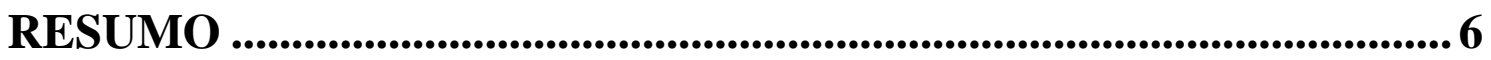

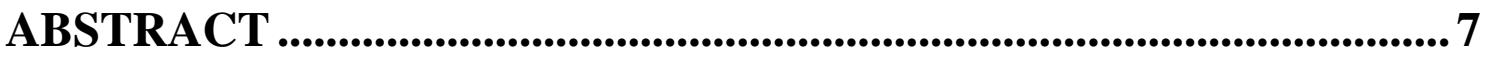

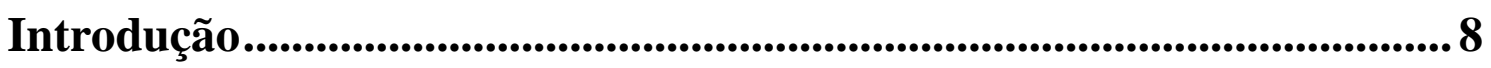

Capítulo 1. Gerativismo e ensino formal de língua materna ................... 11

1.1. Pressupostos da Teoria Gerativa ................................................................................ 11

1.1.1. Considerações sobre os pressupostos teóricos da Teoria Gerativa............................ 13

1.2. O que o professor de ensino básico deve saber sobre linguística - Lúcia Lobato (2003) 14

1.2.1 Considerações sobre a leitura de Lobato (2003) ...................................................... 16

1.3. A gramática do Letrado - Kato (2005) .......................................................................... 17

1.3.1. Considerações sobre a leitura de Kato (2005) ......................................................... 19

1.4. Educação linguística e ensino de gramática na educação básica - Pilati; Naves; Vicente \&

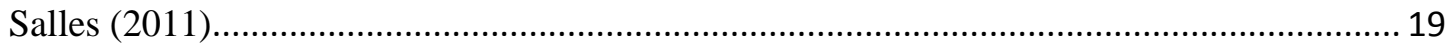

1.4.1. Considerações sobre a leitura de Pilati; Naves; Vicente \& Salles (2011) .................. 22

1.5. Teoria gerativa e "ensino" de gramática: uma releitura dos Parâmetros Curriculares

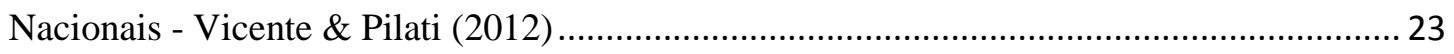

1.5.1. Considerações sobre a leitura de Vicente \& Pilati (2012).......................................... 26

1.6. Contribuições Dos Pressupostos Gerativistas Para A Educação Em Língua Materna -

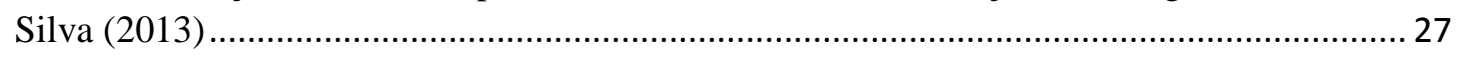

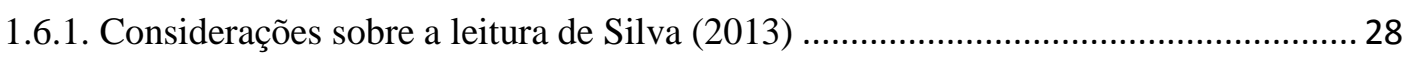

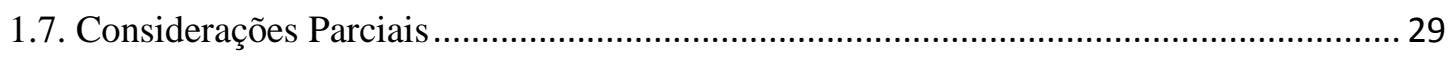

\section{Capítulo 2. Pesquisas sobre a construção do conhecimento e o} desenvolvimento de metodologias e ensino ................................................. 32

2.1. Como as pessoas aprendem: cérebro, mente e escola (2010) .......................................... 32

2.1.1. Considerações sobre a leitura de Como as pessoas aprendem: cérebro, mente e

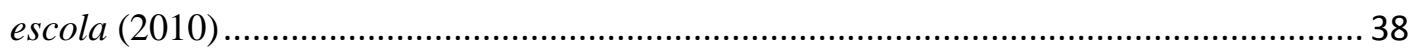

2.2. Approaches and Methods in Language Teaching - Richards \& Rodgers (2001)............. 40

2.2.1. Considerações sobre a leitura de Richards \& Rodgers (2001) .................................. 42

2.3. Creating Significant Learning Experiences - Fink (2003) ........................................... 42

2.3.1. Considerações sobre a leitura de Fink (2003) ........................................................... 44

2.4. Parâmetros Curriculares Nacionais - Brasil (1997)....................................................... 44 
2.4.1. Considerações sobre a leitura dos PCN's (1997)

2.5. Guião de Implementação do Programa de Português do Ensino Básico - Costa et al. (2011) 48

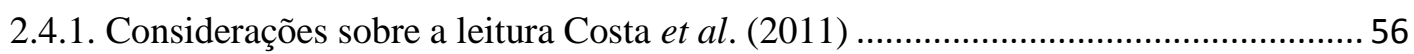

2.6. Considerações sobre o capítulo ....................................................................... 58

Capítulo 3. Aplicação da metodologia e análise de resultados .............. 61

3.1. Pressupostos teóricos sobre a noção de sujeito de predicado....................................... 61

3.1.1. A reflexão crítica de Duarte (2007) sobre os termos da oração .............................. 61

3.1.2. A abordagem de Raposo (2014) para os conceitos de sujeito e predicado............... 64

3.2. Descrição da atividade proposta...................................................................... 67

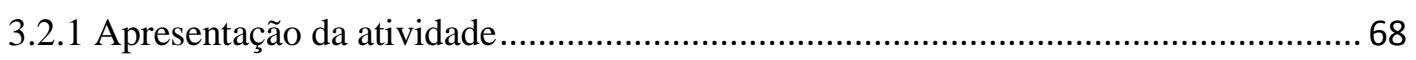

3.2.2 Comentários sobre a elaboração das etapas.................................................... 77

3.3. Metodologia utilizada para a aplicação da atividade............................................... 79

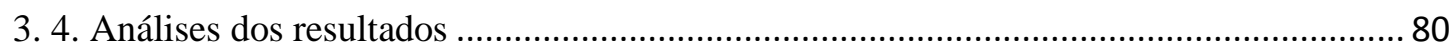

3.4.1. Desempenho dos alunos na resolução dos exercícios ....................................... 80

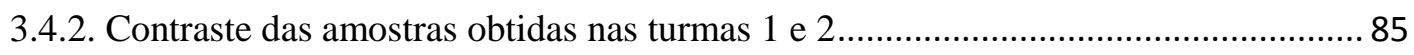

3.5. Considerações Parciais ................................................................................ 88

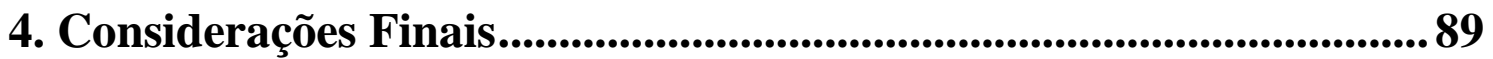

5. Referências Bibliográficas ..................................................................................93 


\section{RESUMO}

Esta dissertação tem objetivo de demonstrar de que forma os princípios relacionados à teoria gerativista, aliados a metodologias que privilegiam a aprendizagem com metacognição, podem contribuir para o ensino de gramática na educação básica. Para tanto, está organizada em três partes principais: (i) o primeiro capítulo, com base em Lobato (2003), Kato (2005), Pilati; Naves; Vicente \& Salles (2011), Vicente \& Pilati (2012) e Silva (2013), desenvolve um arcabouço teórico a respeito de metodologias de ensino de aspectos linguísticos e gramaticais da língua portuguesa, (ii) o segundo capítulo analisa metodologias de ensino de língua desenvolvidas no Brasil e em Portugal para verificar o que há de material disponível para os professores e de que forma tais metodologias podem ser aplicadas em sala de aula com vistas a tornar o ensino de língua portuguesa mais eficaz e (iii) o terceiro capítulo, com base nas ideias de Lobato (2013), Costa et al (2011),Vicente \& Pilati (2012) e Pilati (2014), desenvolve, testa e analisa uma atividade gramatical sobre identificação e classificação do sujeito e do predicado. Os alunos que tiveram contato com o material didático desenvolvido demonstraram uma nítida associação do conteúdo estudado ao conhecimento de mundo que possuem. Pode-se perceber que a abordagem do aprendizado pela descoberta, com metacognição, revela-se um caminho promissor no ensino de língua materna, porque foi possível notar a evolução das respostas dos alunos, com relação à complexidade e ao uso das terminologias e o desenvolvimento do raciocínio destes diante das análises.

Palavras-chave: teoria gerativa, desenvolvimento da aprendizagem, metodologias de ensino, ensino de sujeito. 


\begin{abstract}
This essay will attempt to demonstrate the way the principles related to gerativist theory allied to methodology that emphasizes on metacognition process may help students to learn grammar more effectively. So, it is divided into three main parts: (i) the first chapter, based on Lobato (2203), Kato (2005), Pilati; Naves; Vicente \& Salles (2011), Vicente \& Pilati (2012) and Silva (2013), develops a theoretical framework about teaching methodologies on linguistic and grammatical aspects of Portuguese language, (ii) the second chapter analyses methodologies applied in languages developed in Brazil and Portugal to check out any available material to teachers and how it can be adopted in classrooms to make Portuguese learning easier and (iii) the third chapter, which is based on Lobato ideas (2013), Costa et al (2011), Vicente \& Pilati (2012) and Pilati (2014), advances, tests and analyzes a grammatical activity about identification and arrangement of subject and predicate. Students that were in contact with consolidated didactic material demonstrated a well-marked association of the content and the world they live in. The learning process related to metacognition methodology reveals to be a promising path to mother-tongue teaching, because it was possible to note the evolution of students' feedback related, especially, to the complexity, the use of terminologies and development of reasoning.
\end{abstract}

Keywords: generative theory, development of learning, teaching methodologies, subject teaching. 


\section{Introdução}

Nas últimas décadas, tem-se percebido que a linguística pode oferecer grandes contribuições para o ensino de língua materna. Richard (2004), em seu artigo Why education needs linguistics (and vice versa), defende que a linguística tem uma interface importante com a educação. De acordo com o autor, o ensino da Gramática de modo "tradicional" já está ultrapassado, e as escolas simplesmente o transmitiam (ou transmitem) de geração em geração, sem que houvesse (haja) algum debate ou entendimento. Além disso, tal abordagem não tem raízes na linguística moderna ou mesmo nas linguísticas pré-modernas de séculos anteriores. A Gramática Tradicional, quando utilizada como técnica de ensino, é fragmentária, dogmática e prescritiva, ou seja, muito diferente da linguística moderna.

Como apontado pelo autor, o ensino de língua materna necessita de boas descrições em todas as áreas em que a competência da criança está sendo desenvolvida, desde usar o vocabulário adquirido até a sintaxe e o significado das palavras. E é a linguística que é capaz de fornecer o aparato para que as metodologias de ensino sejam capazes de desenvolver tais competências, pois são dos estudos acadêmicos que resultam as ideias gerais sobre a linguagem e os modelos teóricos para descrever as línguas e analisá-las como sistema.

Pesquisas atuais sobre o tema e sobre a aprendizagem de um modo geral já demonstram que o ensino deve ser baseado no desenvolvimento das capacidades do estudante de identificar padrões significativos de informação, uma vez que são estes que irão fornecer as condições que desencadeiam o acesso ao conhecimento relevante para as tarefas a serem executadas. Ressalta-se também a necessidade de se ter currículos organizados de modo que conduzam à compreensão conceitual, já que normalmente há pouco espaço para o desenvolvimento de ideias importantes e organizadas, de se desenvolverem atividades baseadas na resolução de situações-problema, como uma maneira de ajudar os estudantes a aprender sobre condições de aplicabilidade, com elas os alunos podem aprender quando, onde e por que usar o conhecimento que estão desenvolvendo, ou seja, o conhecimento deve ser "condicionalizado" a fim de ser recuperado quando necessário, caso contrário, este permanece inerte. As informações relevantes devem ser seletivas e facilmente recuperadas, e isso se dá, acima de tudo, com o desenvolvimento da metacognição, um conceito importante que acaba por ser 
fazer também uma habilidade imprescindível para a aprendizagem formal de língua materna.

No entanto, os estudos de Silva (2013) demonstraram que há uma lacuna em relação aos materiais aos quais os professores de língua portuguesa podem se utilizar para construir as metodologias utilizadas nas práticas pedagógicas. A autora fez um levantamento de uma bibliografia que se dedica a orientar as técnicas de ensino e observou que as discussões sobre o desenvolvimento da consciência linguística dos alunos se faz presente em todas as obras, mas que tais abordagens não trabalham de maneira eficaz formas de operacionalizar tais discussões, ou seja, torná-las técnicas a serem aplicadas em sala de aula.

Com base nessas observações e em trabalhos anteriores que vinculam pressupostos gerativistas ao ensino formal de língua materna, esse trabalho apresenta três objetivos principais: (i) desenvolver um arcabouço teórico a respeito de metodologias de ensino de aspectos linguísticos e gramaticais da língua portuguesa usando-se como base os processos cognitivos que ocorrem na aquisição e consolidação dos conhecimentos de língua, (ii) analisar metodologias de ensino de língua desenvolvidas no Brasil e em Portugal com base nos processos de desenvolvimentos do conhecimento e, com isso, verificar o que há de material disponível para os professores e de que forma tais metodologias podem ser aplicadas em sala de aula com vistas a tornar o ensino de língua portuguesa mais eficaz e (iii) testar formas de tornar explícito o conhecimento do idioma a partir do teste de uma atividade desenvolvida analisada em contraste com um exemplar de material didático utilizados pelos alunos.

Para a construção desse trabalho foram contemplados os estudos anteriores de Lobato (2003), Kato (2005), Pilati; Naves; Vicente \& Salles (2011), Vicente \& Pilati (2012) e Silva (2013) a fim de construir um panorama das pesquisas que seguem a perspectiva do gerativismo e o ensino. Com base em tais observações, foram analisadas as abordagens de ensino de língua portuguesa adotadas no Brasil e em Portugal a partir dos conceitos de design instrucional e de aprendizagem significativa de modo a verificar os avanços com relação ao ensino de língua materna que tais abordagens demonstram e os pontos que ainda não correspondem às atuais concepções metodológicas. Por fim, foi elaborada e testada uma atividade baseada no desenvolvimento do conhecimento explícito dos alunos seguindo os seguintes princípios: a) investir em descrições mais adequadas da gramática do português; b) tomar consciência do grau de desenvolvimento linguístico dos alunos e dos aspectos da 
língua que não decorrem de uma aquisição espontânea; c) investir num ensino da língua que capitaliza as regularidades e d) orientar o estudo da gramática em dimensões para além da mera correção do erro (CF. COSTA, 2010).

Diante do exposto, esse trabalho se organiza em três capítulos. No primeiro capítulo, com base nos estudos de Silva (2013), foram estabelecidas relações entre os pressupostos gerativistas e suas contribuições para o ensino a partir de uma análise de estudos anteriores que tratam do tema. Também foi feito um panorama sobre pesquisas recentes relacionadas à teoria gerativista e ao ensino de língua materna. No segundo capítulo foram apresentados estudos sobre a aprendizagem em geral e abordagens de ensino, além de terem sido analisadas as diretrizes adotadas para o ensino de língua portuguesa no Brasil e em Portugal, os PCN's (1997) e o Guião de Implementação do Programa de Português do Ensino Básico (2011) respectivamente. O terceiro capítulo é referente à atividade elaborada e testada com a finalidade de desenvolver a consciência linguística dos alunos. Nesta pesquisa trabalhou-se especificamente com a noção de sujeito gramatical. Para isso, o capítulo apresenta, primeiramente, os conceitos de sujeito e predicado utilizados na elaboração de tal atividade, explica as concepções teóricas subjacentes à atividade e, por fim, apresenta a metodologia de aplicação da atividade e os resultados obtidos. 


\section{Capítulo 1. Gerativismo e ensino formal de língua materna}

Este capítulo tem o objetivo de estabelecer relações entre os pressupostos da teoria gerativa e suas contribuições para o ensino, seguindo Silva (2013) além de construir um panorama com pesquisas recentes feitas dentro da perspectiva do gerativismo e ensino. Serão apresentados e analisados os seguintes trabalhos: Lobato (2003), que defende a necessidade de se trabalhar a gramática como algo dinâmico, interno ao indivíduo; Kato (2005), que traz um estudo pioneiro no sentido de caracterizar teoricamente a gramática do letrado, ou seja, a gramática que se desenvolve no indivíduo durante o período da escolarização; Pilati, Naves, Vicente \& Salles (2011), que discutem o estudo de gramática na educação básica, tomando como referência os pressupostos da gramática gerativa; Vicente \& Pilati (2012), que demonstram de que maneira os pressupostos teóricos do Gerativismo podem contribuir para o desenvolvimento de metodologia inovadora de ensino de Língua Portuguesa e Silva (2013) que faz um levantamento bibliográfico das contribuições dos estudos gerativistas para a educação em língua materna.

\subsection{Pressupostos da Teoria Gerativa}

Noam Chomsky (1950 e trabalhos subsequentes) desenvolve sua teoria com base em uma visão internalista da linguagem, na qual esta (a linguagem) é concebida como algo inato aos seres humanos, um "resultado da inter-relação de dois fatores: o estado inicial e o curso da experiência." (Chomsky, 2005, p. 31). De acordo com a teoria, existe no corpo humano uma expressão de genes responsável pela interação de tais fatores, algo que corresponderia a um "órgão da linguagem", o que a teoria denomina de Faculdade da Linguagem.

\footnotetext{
A faculdade da linguagem pode perfeitamente ser considerada um 'órgão da linguagem', no sentido em que os cientistas falam do sistema visual, do sistema imunológico ou do sistema circulatório como órgãos do corpo. Entendido dessa maneira, um órgão não é algo que possa ser removido do corpo, deixando o resto intacto. Trata-se de um subsistema de uma estrutura mais complexa. (Chomsky, 2005, p. 31)
}

À base sobre a qual a língua se desenvolve é dado o nome de Gramática Universal (GU), conforme Chomsky (1981). Sob essa condição, o indivíduo possui uma 
matriz biológica, que fornece uma estrutura dentro da qual se dá o desenvolvimento da linguagem. Segundo Chomsky (1981:175), pode-se encarar a GU como o próprio programa genético, ou seja, o que permite as línguas humanas possíveis.

\begin{abstract}
Podemos conceber o estado inicial como um "sistema de aquisição da linguagem", que toma a experiência como input e fornece a linguagem como output - um output que é internamente representado na mente/cérebro. $\mathrm{O}$ input e o output são ambos passíveis de análise: podemos estudar o curso da experiência e as propriedades das linguagens adquiridas. Aquilo que é aprendido dessa maneira pode fornecer-nos muitas informações sobre 0 estado inicial que faz a mediação entre elas. (Chomsky, 2005, p. 32)
\end{abstract}

Segundo a teoria, o estado inicial, a (GU), não é um estado vazio, mas sim o conjunto de princípios que regem as línguas naturais somados aos parâmetros que são fixados pelo input recebido no curso da experiência, ou seja, pela língua a ser adquirida na infância.

(...) a Gramática Universal (GU) é postulada como o estado So inicial, comum a todas as crianças, homogêneo dentro da espécie humana. Longe de ser um estado vazio, a GU é definida como o conjunto dos Princípios invariantes que regem as línguas naturais e mais os Parâmetros de variação interlinguística, concebidos como opções presentes [+ ou 1] ou ausentes [- ou $\varnothing]$. Logo, uma boa parte da língua-I já está em So , isto é, é inata ou bioprogramada. Os Princípios não são aprendidos; quando muito maturam. Os Parâmetros também já estão previstos, mas, por serem propriedades subespecificadas, precisam ser definidos quanto ao seu valor [+/1 ou -/0], através do "input" que a criança recebe de sua comunidade.

As propriedades paramétricas são pressupostas como sendo em número finito, e sua fixação, positiva ou negativa, como dependente exclusivamente de dados positivos. A aquisição não se desenvolve através de correções ou de instruções. É um processo seletivo e não instrucional. (Kato, 2002, p. $311-312$ )

O input, que seria o estímulo recebido do ambiente, não precisa, segundo Chomsky, ser regulado e monitorado, ou seja, a criança pode ser estimulada em excesso ou deficientemente, o resultado será que a GU usará quais forem os estímulos a fim de organizar o sistema linguístico na mente. Esse entendimento se resume no conceito Argumento da Pobreza de Estímulo, pois, segundo Chomsky (1970, p.35), a fala normal consta, em grande parte, de fragmentos, inícios interrompidos, misturas, e outras distorções. No entanto, as crianças são capazes de estabelecer parâmetros de sua língua materna baseados em princípios que subjazem todas as línguas naturais.

Também são relevantes para este trabalho os conceitos gerativistas de Criatividade, Competência e Desempenho. A criatividade corresponde à capacidade dos seres humanos, em fase de aquisição da língua materna, de produzir sentenças ainda que não as tenha ouvido anteriormente. $\mathrm{O}$ desempenho se trata do que seria a performance, $\mathrm{o}$ 
uso, que é determinado pelo contexto em que está inserido o falante. E a competência é capacidade inata que o indivíduo tem de produzir, de compreender e de reconhecer as frases de sua língua, tanto as existentes como as possíveis construções.

\subsubsection{Considerações sobre os pressupostos teóricos da Teoria Gerativa}

Como se pode observar na seção anterior, a teoria gerativa possui uma abordagem "mentalista" da linguagem. A teoria concebe a linguagem como uma propriedade inata aos seres humanos, que possuem um "órgão" destinado à aquisição de um idioma, a Faculdade da Linguagem, tal aquisição se dá, portanto, e maneira natural e espontânea, não necessitando de nenhuma instrução formal.

Silva (2013) observa, entretanto, que Chomsky contempla a existência de uma predisposição humana para aquisição de uma língua oral, mas que seu estudo não engloba o aprendizado da escrita, uma vez que este não é biológico como a fala e, sim, social. Além disso, também não vincula sua teoria ao ensino; no entanto, uma concepção da linguagem como algo inato ao ser humano interfere na visão sobre do ensino de língua materna, uma vez que muda o olhar do professor em relação ao aluno, pois este não é mais visto como uma tábula rasa, mas sim como alguém que já traz um conhecimento inconsciente da estrutura de seu idioma materno. Caberia, portanto, ao ensino trazer tal conhecimento à consciência, tornando o aluno apto a manipular de maneira reflexiva a estrutura de seu idioma.

Ainda segundo Silva (2013), conhecimentos sobre os conceitos formadores da teoria, tais como: Aquisição de linguagem, Input, GU, Argumento da pobreza de estímulo, Criatividade, Competência e Desempenho são importantes para professores de língua materna por oferecerem subsídios teóricos fundamentais para o entendimento da natureza do conhecimento linguístico dos indivíduos.

O trabalho em sala de aula pode ser reestruturado a partir da compreensão da natureza da linguagem. A hipótese da Aquisição da Linguagem nos revela que não aprendemos uma língua. O que ocorre é o desenvolvimento da gramática de nossa língua materna na mente, isso é, fixamos os parâmetros da gramática que estamos a adquirir. Observar nos alunos como essa gramática se desenvolve pode oferecer ao professor subsídios para que perceba as estruturas linguísticas que já foram adquiridas pelos alunos e as que eles ainda aprenderão. Isso ainda nos lembra de que o aluno já 
inicia seus estudos com um conhecimento prévio do idioma, conhecimento este que não foi desenvolvido em séries anteriores, mas que é fruto da experiência, ou melhor, da soma de dois outros conceitos importante: Gramática Universal e Input.

Tais observações fazem com que o trabalho em sala de aula não possa prescindir dos conhecimentos que o aluno já possui, uma vez que este é Competente em sua língua. Espera-se, na verdade, que os alunos desenvolvam tais conhecimentos, os quais, a princípio, são inconscientes, e sejam capazes de manipular conscientemente as estruturas da língua, ou seja, o trabalho do professor estaria relacionado ao Desempenho do aluno. O desenvolvimento do que seria a "consciência sintática", ou conhecimento explícito da língua, é facilitado por uma apurada seleção e organização do input a ser oferecido em sala de aula. É essa necessidade de organização e seleção de tal input que nos faz refletir sobre as práticas pedagógicas, desde a organização metodológica até a seleção do material didático a ser utilizado em sala, temas a serem tratados nos capítulos 2 e 3 deste trabalho.

\subsection{O que o professor de ensino básico deve saber sobre linguística - Lúcia Lobato (2003)}

Sob o olhar da gramática como algo dinâmico e interno, Lobato (2003) faz uma reflexão sobre a necessidade de o professor da educação básica conhecer os estudos linguísticos. A autora considera fundamental o professor ter conhecimento de questões linguísticas gerais, uma vez que pode se deparar em sala de aula com conceitos e nomenclaturas imprecisas. No entanto, Lobato (2003) ressalta que é importante precisar que tipo de conhecimento sobre linguística o professor deve ter, uma vez que este se depara com um grande abismo entre o conhecimento sobre estrutura linguística desenvolvido nas Universidades e o conhecimento gramatical que compõe as gramáticas escolares e, por outro lado, não se objetiva transformar em linguista o professor de língua do ensino básico.

A autora busca esclarecer as duas acepções que se pode ter de gramática: 1. A gramática como algo estático: um conjunto de descrições e 2. A gramática como um constructo mental: dinâmica, interna ao indivíduo e com propriedades explicativas do caráter criativo do uso das línguas naturais. Diante dessa diferenciação, a autora ressalta a importância de ser trabalhada em sala de aula essa $2^{a}$ noção de gramática, ou seja, não existiria a necessidade de ensinar gramática ao aluno como algo externo a ele, pois este 
já chega à sala de aula com a gramática de sua língua internalizada e com propriedades que lhe permitem o uso criativo da linguagem. Tendo isso em vista, Lobato (2003) aponta uma metodologia de ensino pautada em:

- $\quad$ Procedimentos de descoberta - levar o aluno à descoberta de novas informações com base na análise de estruturas de sua língua.

- Metodologia de eliciação - metodologia que direciona o aluno a tirar conclusões a partir da análise dos dados. É uma maneira de acelerar o procedimento de descoberta.

- Técnica de resultados - consiste em trabalhar com estruturas dando ênfase ao fato de que a cada estrutura corresponde certo resultado semântico.

Com essa técnica o aluno verificaria por si próprio que o ensino gramatical tem uma razão de ser, pois percebe que sentido obtém com tal ou qual estrutura. Contribuindo, consequentemente, para o seu domínio do texto, uma vez que manipularia as estruturas conforme o resultado semântico que deseja obter. (Lobato, 2003, p. 6)

A autora demonstra que o trabalho em sala de aula com a concepção de gramática como algo biológico requer ampla difusão de tal perspectiva, assimilação de tal conceito por parte dos professores e, consequentemente, uma mudança no conteúdo programático.

Além disso, a autora aponta a necessidade de uma análise mais precisa das relações gramaticais, noções como sujeito e objeto, por exemplo, a classe dos verbos, uma vez que a gramática tradicional ainda não trata dos verbos inergativos $\mathrm{e}$ inacusativos, da classificação das orações e, principalmente, uma mudança de postura ante as análises linguísticas.

A autora acredita que a mudança no que diz respeito aos conhecimentos teóricos, deva ocorrer "aos poucos" no ensino básico, no entanto afirma que a mudança metodológica deva ser imediata, as análises linguísticas devem partir dos dados, com adoção do procedimento de descoberta, da metodologia de eliciação e da técnica dos resultados.

Fica claro no texto, que Lobato acredita na mudança em relação ao ensino de gramática e não que este deva ser deixado de lado. Para comprovar a necessidade do ensino de gramática, a autora nos apresenta três motivos pertinentes: 1. o fato de que subjaz ao texto e às atividades discursivas em geral a mesma gramática abstrata que subjaz às palavras, aos sintagmas, às orações e às frases, 2. porque a explicitação dos mecanismos gramaticais e de seus efeitos semânticos ajudam o aluno a ganhar tempo no 
seu processo de domínio das atividades discursivas em geral e 3. usando adequadamente o método proposto pela autora, o aluno chegará por si próprio à conclusão de que existe uma faculdade de linguagem.

\subsubsection{Considerações sobre a leitura de Lobato (2003)}

Lobato (2003) traz grandes contribuições para o ensino de gramática quando organiza uma metodologia de ensino pautada nos pressupostos gerativista que nos disponibiliza três importantes técnicas para a aprendizagem de língua materna: procedimentos de descoberta, eliciação e técnica de resultados. No entanto é importante ressaltar que, no que diz respeitos aos conceitos apresentados pela autora, já se encontram análises que tratam da eliciação não como uma metodologia, mas sim como uma técnica de ensino (Vicente \& Pilati, 2012), uma vez que corresponde a uma atitude a ser tomada pelo professor em relação ao seu aluno em sala de aula, pois se trata de extrair do aluno uma informação previamente conhecida. Para a eliciação ser uma metodologia, seria necessário que correspondesse a um plano global para a apresentação ordenada do conteúdo sobre a língua (Richards \& Rodgers, 2001). As diferenças em relação à metodologia e técnica, caso não pareçam muito claras nesse momento, ainda serão tratadas de maneira mais específica no capítulo 2 deste trabalho.

Outro ponto importante a se observar nas afirmações da autora, diz respeito à sua conclusão acerca do uso da metodologia por ela proposta, de acordo com Lobato (2003), a partir do uso dos procedimentos de descoberta, das técnicas de eliciação e das técnicas de resultados, o aluno será capaz de chegar por si próprio às conclusões a respeito do funcionamento do idioma. A argumentação da autora não deixa claros os limites da interferência do professor no desenvolvimento dos conhecimentos linguísticos do aluno, ao que parece os dados apresentados pelo material didático seriam suficientes para desenvolver o conhecimento explícito acerca da gramática da língua, não sendo necessárias instruções formais oferecidas pelo professor.

No entanto, tal conclusão a respeito do processo formal de ensino/aprendizagem de língua materna parece ser contraditória, uma vez que a própria autora, e a teoria gerativa de um modo geral, reconhecem que o ensino da modalidade escrita do idioma tem suas especificidades, pois essa habilidade não é inata ao ser humano, como o é a modalidade oral da língua, e, por conta disso, não ocorre de maneira natural e 
espontânea, sendo necessárias, portanto, instruções específicas para que se desenvolva, o que faz com que o professor tenha papel importante nesse processo, pois é ele quem vai direcionar esse processo e auxiliar tal desenvolvimento.

\subsection{A gramática do Letrado - Kato (2005)}

Nesse estudo, a autora demonstra as semelhanças entre aquisição de L2 e aprendizagem da escrita e a natureza de suas regularidades e arbitrariedades. $\mathrm{O}$ estudo apresenta uma discussão teórica sobre o conhecimento linguístico do letrado, levando em consideração o conceito de GU para a língua oral e para a gramática do falante escolarizado.

Para Kato (2005), diferentemente do que acontece em Portugal, a aquisição da gramática no Brasil assemelha-se à aprendizagem de L2, pois:

\footnotetext{
as duas aprendizagens são socialmente motivadas e não biologicamente determinadas;

- $\quad$ nos dois casos, o início da aprendizagem começa, em geral, depois da idade crítica para a aquisição ;

- $\quad$ o processo, nos dois casos é, essencialmente, consciente;

- acredita-se, nos dois casos, que o sucesso depende de dados positivos e negativos;

- em geral, o processo nas duas "aquisições" é vagaroso e não instantâneo;

- $\quad$ nos dois casos, há mais diferenças individuais. (Kato, 2005, p. 6)
}

Com isso, a autora discute a caracterização da gramática do letrado no português do Brasil sob a investigação de três hipóteses: 1. O processo de letramento poderia recuperar o conhecimento gramatical do indivíduo em alguma época passada do PB. 2. O processo de letramento privilegia a unidade linguística. 3. O conhecimento linguístico brasileiro se define como algo distinto das duas hipóteses.

Tendo em vista que a autora compara a aquisição da gramática do letrado do PB à aquisição de um L2, Kato (2005) questiona se as teorias sobre aquisição de L2 podem oferecer alguma contribuição para o entendimento de tal gramática e com isso apresenta duas hipóteses presentes da literatura sobre a aquisição da gramática de L2: 1. A hipótese do não cesso à GU, nem direto, nem indireto, sendo assim, a aprendizagem se 
dá por meio de um mecanismo multifuncional e 2. A aquisição de L2 se dá via acesso indireto à GU, ou seja, por meio da L1.

Sendo assim, a autora formula duas hipóteses pelas quais poderia se dar o desenvolvimento da escrita: nenhum acesso à GU ou um acesso indireto à GU por meio da gramática da fala. Para Kato (2005), há evidências comportamentais na aprendizagem da escrita, como erros de esquiva e hipercorreções, que a fazem concluir que a morfossintaxe aprendida na escola tem estatuto estilístico e não gramatical. No processo de letramento, a escola procura recuperar perdas linguísticas, uma vez que as inovações são inapropriadas para a escrita, no entanto a gramática do letrado brasileiro acaba por não corresponder nem a uma gramática de um falante letrado do passado nem à de um letrado português.

Com base nos trabalho de Hershensohn (2000), Kato (2005) defende a tese do acesso indireto à GU na L2 e na escrita e afirma que a escrita é restringida pelos mesmos Princípios da GU, que faz uso das mesmas categorias e funções, e que as operações gramaticais nelas presentes são previstas pelos Parâmetros da GU.

Partindo do pressuposto de que há acesso à GU, Kato (2005) passa a questionar como este se dá. Sobre esse assunto, investiga as teorias de Roeper (2000), que trata do bilinguismo universal, e Silva-Corvalán (1986) sobre as propriedades gramaticais e periféricas das línguas semelhantes à L1.

Em resumo, para delimitar o estatuto da "gramática" da escrita na mente do falante, Kato (2005) considera duas hipóteses para a aquisição de uma "segunda gramática" (G2): 1. o falante letrado tem duas gramáticas nucleares, como um bilíngue "stricto sensu" tardio, G1 e G2 como gramáticas distintas, seja por acesso total na concepção de Roeper, ou via permeabilidade das gramáticas, na concepção de acesso indireto de Silva-Corvalán; e 2. o falante letrado é um bilíngue desigual que tem, em sua Língua-I, uma periferia marcada maior do que a dos não letrados.

Para Kato (2005), a G2, em sua concepção, não tem a mesma natureza da G1, o que se chama de "G2" seria constituído, não por seleção paramétrica, mas por "regras estilísticas", selecionadas arbitrariamente de gramáticas passadas ou emprestadas da gramática portuguesa, no entanto a autora ainda considera que a "G2" não deixa de ser, também, um subproduto da GU. 


\subsubsection{Considerações sobre a leitura de Kato (2005)}

O trabalho de Kato (2005) aborda conceitos fundamentais para a investigação de questões relacionadas à aquisição linguística. No entanto a autora não deixa claro se o desenvolvimento da escrita deva ser tratado ou não como uma G2 propriamente dita, ou apenas como uma gramática periférica.

Ainda que não seja o objetivo deste trabalho levantar com afinco tal discussão, é importante esclarecer que, acredita-se aqui, que o fato de a "gramática" da escrita ter acesso indireto à gramática da fala e por não se constituir a partir da seleção paramétrica, mas sim por regras estilísticas armazenadas e utilizadas de maneira arbitrária, não se permite que esta seja considerada uma gramática nuclear semelhante a uma L2, ou seja, uma G2, mas sim que esta se caracteriza como uma periferia marcada, a qual ainda necessita de mais investigações sobre sua natureza no sentido de delimitar melhor suas características, regularidades ou irregularidades, se houvesse.

\subsection{Educação linguística e ensino de gramática na educação básica - Pilati; Naves; Vicente \& Salles (2011)}

No artigo, as autoras discutem o estudo de gramática na educação básica, tomando como referência os pressupostos da gramática gerativa, dentre os quais discutem principalmente as noções da Faculdade da Linguagem e de Competência para o ensino. Nesse trabalho, propõe-se uma metodologia de ensino de gramática baseada na formulação de hipóteses e no raciocínio inferencial.

Ao tratarem do lugar da gramática no componente curricular Língua Portuguesa, é trazida como objeto de debate a necessidade de renovação das práticas didáticas, tendo sido essa já apontada por Ilari (1985) quando discutiu a renovação dos profissionais responsáveis pelo ensino de línguas.

As autoras demonstram que, nos Parâmetros Curriculares Nacionais, as questões sobre as abordagens e metodologias de ensino aparecem como objetos inacabados. De acordo com o documento, estes seriam tópicos de constante análise, no entanto tal postura adotada pelos PCN's ressalta, segundo as autoras, o importante papel das Universidades, uma vez que são as responsáveis pela difusão dos conhecimentos sobre Linguística e, principalmente, pela formação dos professores. 
Tendo isso em vista, as autoras apresentam uma proposta de ensino científico da gramática no âmbito da educação linguística, segundo elas:

propõe-se, na presente discussão, promover o estudo gramatical em uma perspectiva científica, tendo em vista a existência de aparato(s) teórico(s) adequado(s) à caracterização das variedades linguísticas e de fenômenos gramaticais ligados às práticas discursivas. Nesse contexto, em que surgem novos rumos para o ensino gramatical na Educação Básica, nossa proposta é que a língua portuguesa, a(s) língua(s) indígena(s) e a LIBRAS e a língua estrangeira (inglês e espanhol, francês, as línguas de imigrantes, de acordo com as demandas de cada comunidade) figurem como objeto de análise científica, no confronto com outras línguas, diante do pressuposto de que sua manifestação é determinada por um conhecimento inato - a competência linguística. (Pilati; Naves; Vicente \& Salles, 2011, p. 399-400)

Pilati; Naves; Vicente \& Salles (2011), no entanto, ressalvam que o ensino científico da gramática implica a formação do professor de língua com a noção de língua como algo inato e que cabe ao professor o papel de tornar explícito esse conhecimento que o aluno já tem internalizado.

Defendemos, portanto, que um objetivo fundamental do ensino de língua é desenvolver no aluno uma habilidade de reflexão sobre a língua que se torne cada vez mais refinada, com implicações para sua produção oral e escrita em língua portuguesa - e nas diferentes línguas a que tenha acesso, seja no caso das comunidades bilíngues, seja em relação à língua estrangeira. (Pilati; Naves; Vicente \& Salles, 2011, p. 400)

As autoras deixam claro, que não se pretende abandonar outras abordagens o ensino, mas sim complementá-las, buscando elaborar uma metodologia que considere a visão estrutural e interna da língua.

A questão que se coloca como desafio é levar em conta o fato de haver um saber linguístico inato na hora de formular a apresentação dos conteúdos, uma vez que alguns aspectos linguísticos não são ensinados, mas apenas explicitados, enquanto que outros aspectos precisam ser ensinados por estarem associados a questões político-culturais.

O que ocorreu com o "ensino" de gramática, de acordo com as autoras, é que a tradição gramatical promoveu uma inversão de valores, na qual os estudantes não são ensinados a desenvolverem suas habilidades linguísticas e acabam sendo tratados como desconhecedores da língua que usam no dia a dia, ou seja, são colocados numa posição de aprendizado passivo, em que não se leva em consideração os conhecimentos que os alunos já possuem. 
Para tratar da realidade vivenciada pelos professores na abordagem gramatical em sala de aula e da proposta alternativa, pautada no conceito de competência linguística, que as autoras apresentam para dar conta dessa situação, são tratados três aspectos do estudo gramatical, desde a maneira como são tratados por diferentes gramáticos até os problemas que esses diferentes tratamentos resultam para o ensino, sendo, portanto, abordadas: a transitividade, a regência verbal e a ordem das palavras.

No que diz respeito à transitividade, as autoras apontam que o problema, ou ao menos um deles, está nas definições encontradas nas gramáticas, pois estas não são sistematizadas e acabam por aparecer de maneira circular, em que a definição de um conceito depende do estudo de outras funções sintáticas. Pilati; Naves; Vicente \& Salles (2011) acreditam que a análise gramatical deva lidar com diferentes tipos de dados e, uma vez que os estudantes não realizam construções que estejam em desacordo com sua língua, pois são dotados de competência linguística, estes são capazes de lidar intuitivamente com as questões gramaticais, o que permite um trabalho realizado a partir da produção e da compreensão de textos dos próprios estudantes, em vistas a levar em consideração o conhecimento internalizado e construir as definições a partir da análise dos dados, e não o contrário.

Com relação à regência verbal, as autoras demonstram que, apesar de o termo ter uma acepção muito mais ampla, os materiais didáticos costumam a limitá-lo à questão do uso da proposição.

\footnotetext{
Essa discussão vem formulada, geralmente, em termos das distinções de significado produzidas pela presença versus ausência da preposição, sem que se questione o fato de que a flutuação da preposição é, em alguns casos, condicionada por fatores estruturais, ou ainda que o uso preposicionado ou não de uma forma verbal está associado a variações translinguísticas e/ou transdialetais. (Pilati; Naves; Vicente \& Salles, 2011, p. 409)
}

Pilati; Naves; Vicente \& Salles (2011) consideram que a descrição gramatical acaba por se concentrar no contraste de significado que a distribuição da preposição promove, o que resulta em uma prática escolar na qual os alunos memorizam os casos relevantes, correlacionando tal distribuição aos significados correspondentes. Com isso, as autoras sugerem que se demonstre a distribuição da proposição associada a fatores estruturais e a contextos de complementação.

Ao tratar da do fenômeno da ordem nas gramáticas tradicionais, as autoras dividem a discussão em duas partes: 1. A ordem dos termos no sintagma nominal, em 
que as autoras sugerem técnicas de eliciação para mostrar ao aluno que ele conhece as regras da gramática de sua própria língua, trabalhando restrições sintáticas, correlações entre a estrutura sintática e a estrutura semântica e a distribuição propriamente dita, trabalhando assim a análise gramatical em três níveis: morfológico, semântico e sintático. 2. A ordem dos termos na oração, na qual propõem uma metodologia que, baseada na investigação e na busca de possibilidades de expressão, promova uma reflexão sobre a língua, de modo que os alunos alcancem os resultados a partir do conhecimento inato que possuem e cheguem a uma prática mais consciente dos recursos linguísticos. Tal metodologia se baseia na: apresentação e análise dos dados, eliciação das regras, elaboração de conclusões e prática textual.

Por fim, as autoras consideram que a educação linguística tem por objeto de análise a diversidade linguística, o que permite desenvolver práticas pedagógicas que sejam inovadores no trabalho com a gramática e que propiciem não só a compreensão das propriedades das línguas em suas múltiplas manifestações, mas também o desenvolvimento do uso consciente das estruturas da língua.

\subsubsection{Considerações sobre a leitura de Pilati; Naves; Vicente \& Salles (2011)}

No artigo apresentado, observa-se que as autoras oferecem reflexões mais específicas e aprofundadas com relação ao ensino de língua portuguesa no Brasil. Ao tratarem dos PCN's, que seriam os responsáveis para direcionar o tratamento dos conteúdos abordados em sala de aula, oferecem reflexões consistentes e sugerem uma discussão acerca das reais metodologias de ensino adotadas no Brasil, pois, uma vez que o documento não é claro a esse respeito, permite-se pressupor que não há uma uniformidade metodológica, ou melhor, não há uma sistematização das metodologias a serem adotadas no ensino de língua portuguesa no brasil.

Quanto ao tratamento específico que Pilati; Naves; Vicente \& Salles (2011) dão a determinados conteúdos gramaticais, como regência verbal, transitividade e ordem das palavras, acabam por oferecer subsídios para que se promovam alterações não apenas nas metodologias adotadas, como também nos materiais didáticos disponíveis para os professores. O texto acaba por apresentar exemplos viáveis, que, a princípio, parecem corresponder à metodologia proposta pelas autoras, baseada na competência linguística dos alunos, mas que não correspondem ao tratamento que é dado em sala de aula a esses 
conteúdos gramaticais, o que caba por reforçar a necessidade de renovação no ensino de língua.

As autoras apresentam um trabalho no qual sugerem soluções promissoras para as questões pedagógicas, no entanto, devido à linguagem do texto, a discussão que suscitam parece permear, assim como outras tantas, apenas o mundo acadêmico, não parecendo estar disponível para o acesso e o entendimento dos professores atuantes na educação básica.

\subsection{Teoria gerativa e "ensino" de gramática: uma releitura dos Parâmetros Curriculares Nacionais - Vicente \& Pilati (2012)}

Vicente \& Pilati (2012) têm como objetivo demonstrar de que maneira os pressupostos teóricos da Teoria Gerativa "podem contribuir para o desenvolvimento de uma metodologia inovadora de ensino de Língua Portuguesa" (Vicente \& Pilati, 2012, p.4), além de demonstrarem, também, como os pressupostos de tal teoria se mostram consonantes com os Parâmetros Curriculares Nacionais (PCNs).

Em seu trabalho, são apontadas algumas passagens dos PCNs que abrem espaço para a aplicação de alguns pressupostos básicos do Gerativismo, tais como "faculdade da linguagem", "competência" e "criatividade", ainda que então haja menção direta a tais conceitos no documento. No entanto, no que diz respeito ao "conhecimento prévio", este é tratado diretamente em tais diretrizes:

\footnotetext{
Com o deslocamento do eixo da investigação das questões do ensino para as questões da aprendizagem, foi possível compreender que as crianças sabiam muito mais do que se poderia supor até então, que elas não entravam na escola completamente desinformadas, que possuíam um conhecimento prévio. (PCNs, 2000, p. 20)
}

Porém, é importante frisar que tal tratamento não corresponde ao sentido chomskyano de "conhecimento prévio", o texto considera como tal aquele conhecimento aprendido previamente na escola, enquanto que a Teoria Gerativa o trata como um conjunto de conhecimentos inatos aos seres humanos, o que seria a "competência linguística" para tal teoria, ou seja, o conhecimento que o falante tem de sua própria gramática que antecede o ensino formal e explícito oferecido pela escola, restando a esta, de acordo com as autoras: 
a) alfabetizá-lo - mostrar ao aluno a relação entre os sons e as letras; b) promover o letramento do aluno - mostrar os valores sociais dos diferentes textos e gêneros e c) desenvolver a capacidade de expressão escrita e oral do aluno, dentro de uma perspectiva de padronização e de desenvolvimento de técnicas de expressão escrita. (Vicente \& Pilati, 2012, p. 8).

Diante disso, é apresentada pelas autoras a necessidade de mudança no papel do professor em relação à aprendizagem, uma vez que este passa a ser um mediador no processo de trazer à consciência tais conhecimentos inatos, ou seja, o foco deixa de ser uma metodologia de "como se ensina" e passa a ser uma metodologia baseada em "como se aprende", a fim de se articular teoria e prática, linguística e ensino, tendo sempre como base o conhecimento linguístico prévio que o estudante traz para a escola e, como finalidade, que este saiba manejar o idioma a partir da aprendizagem de estruturas próprias da língua escrita, além da metalinguagem que o estudo da gramática envolve.

No artigo é apresentada uma análise dos PCNs a partir de comentários acerca de trechos do documento. Reconhece-se a perspectiva sócio-interacionista que este adota em relação à linguagem, segundo a qual se conceitua língua como:

\footnotetext{
um sistema de signos histórico e social que possibilita ao homem significar o mundo e a realidade. Assim, aprendê-la é aprender não só a conhecer as palavras, mas também os seus significados culturais e, com eles, os modos pelos quais as pessoas do seu meio social entendem e interpretam a realidade e a si mesmas. (PCNs, 1998, p. 24)
}

Além disso, de acordo com as autoras, observa-se a influência de outras correntes linguísticas na redação dos parâmetros. Como observado na análise, ao tratar a língua como "sistema de signos", tem-se uma perspectiva da linguística textual, como também valoriza-se a natureza social e interativa da linguagem ao considerar a língua em um processo discursivo do pensamento simbólico.

A problemática dos PCNs apresentada por Vicente \& Pilati (2012) é que, apesar de oferecer espaço para aplicação dos pressupostos gerativistas, este permite a interpretação de que a abordagem da gramática em sala de aula deixa de ser uma prioridade no processo de aprendizagem formal da língua materna, como aponta o recorte feito pelas autoras: 
(...) $[\mathrm{O}] \mathrm{s}$ aspectos gramaticais - e outros discursivos como a pontuação devem ser selecionados a partir dos das produções escritas dos alunos (...). Isso não significa que não é para ensinar fonética, morfologia ou sintaxe, mas que elas devem ser oferecidas à medida que se tornarem necessárias para a reflexão sobre a língua. (PCNs, 2000, p. 90)

$\mathrm{O}$ eixo USO $\rightarrow$ REFLEXÃO $\rightarrow$ USO, segundo o qual o documento aponta que devem ser organizados os conteúdos de Língua Portuguesa, tem como ponto de partir a produção escrita dos alunos e não a reflexão sobre aquilo que o aluno já sabe sobre sua língua, como sugere as autoras, um eixo baseado na REFLEXÃO $\rightarrow$ USO $\rightarrow$ REFLEXÃO $\rightarrow$ USO.

Outra crítica que se faz na análise é quanto à falta de orientação em relação à elaboração e realização de atividades gramaticais relacionadas às práticas textuais. $\mathrm{O}$ documento propõe que as atividades sistematizem a linguagem interiorizada pelo aluno, incentivando a sua verbalização e o domínio de outras variedades linguísticas. No entanto, não apresenta exemplos, ou seja, formas práticas para que os objetivos propostos sejam alcançados.

Diante disso, as autoras oferecem uma reflexão acerca do papel do professor como um "agente eliciador de conhecimento linguístico". Para isso utilizam-se da argumentação de Lobato (2003) na qual, no processo de ensino de língua materna, devese adotar o "procedimento de descoberta", promovendo a consciência dos fatos linguísticos nos alunos de maneira natural e espontânea, partindo do contato destes com a informação a ser transmitida e estando, em sala de aula, aliado ao uso de técnicas de eliciação, ato de extrair dos alunos informação previamente conhecida, antes que a eles seja apresentado conteúdo novo, uma maneira de mostrar ao aluno que este é parte ativa no processo ensino-aprendizagem, ou, "o sujeito da ação de aprender, aquele que age sobre o objeto de conhecimento" (PCNs, 2000, p. 29).

Tendo em vista o fato de os alunos já possuírem conhecimentos gramaticais de sua língua antes de ingressarem na escola, as autoras usam o termo "ensino" entre aspas ao longo do texto como uma maneira de defender que a escola não ensina gramática ao aluno, pois quando a sua frequência à escola se torna obrigatória, este já tem conhecimento da gramática de sua língua. Diante dessa atitude das autoras ao tratar do termo em questão, observa-se aqui que a palavra "ensino" também passará a ser tratada entre aspas ao longo desse trabalho pelo fato de estarmos de acordo com tais observações e reconhecer a pertinência delas no tratamento das metodologias de "ensino" de língua materna. 
Ressalta-se, entretanto, que o fato de o aluno ser sujeito ativo na aprendizagem não descarta ou esvazia a função do professor nesse processo. O estudante não irá sozinho construir seu conhecimento, o professor passa a ser um mediador, o que implica uma mudança de metodologia e não sua ausência nesse processo.

Diante da falta de direcionamento mais preciso dos PCNs quanto à elaboração de das atividades de sistematização do conhecimento linguístico, as autoras sugerem temas pouco explorados na gramática tradicional, que poderiam instigar a consciência linguística dos alunos, tais como:

- Construções ambíguas - que acabam por abordar correlações entre estrutura sintática e estrutura semântica;

- (In) transitividade verbal - uma vez que os verbos não se dividem apenas em transitivos e intransitivos, mas que estes últimos ainda subdividem-se em inergativos e inacusativos, o que pode fazer com que os alunos não entendam o comportamento de verbos que podem alternar entre uma manifestação intransitiva e outra transitiva, e outros verbos que não se comportam da mesma maneira.

Além da investigação de outros temas, como: topicalização, clivagem e objeto nulo, uma vez que são praticamente ignorados pela gramática tradicional.

\subsubsection{Considerações sobre a leitura de Vicente \& Pilati (2012)}

Observa-se que o trabalho das autoras se revela, em alguns momentos, uma evolução do trabalho de Lobato (2003). Foi aperfeiçoado o conceito de metodologia de eliciação, a qual deixa de ser tratada como metodologia e passa a ser tratada como técnica, por corresponder a uma atitude executada em sala de aula, como apontado na sessão anterior. Além disso, o papel do professor está mais precisamente estabelecido como um mediador no processo de construção do conhecimento por parte do aluno. Fica claro na proposta das autoras que tal papel não deve ser esvaziado em sua função, pois, ao contrário do que se pode inferir em Lobato (2003), o aluno não irá, sozinho, construir seu conhecimento.

As autoras, ao tratarem das várias correntes que influenciam a redação os Parâmetros Curriculares Nacionais, não deixam claro quais correntes seriam essas, são apresentadas várias concepções de linguagem, no entanto não se pode afirmar com precisão que tais concepções derivam “várias correntes” de estudo da linguagem. 
O trabalho das autoras consegue articular de maneira mais precisa as questões acerca da teoria diante da prática e da linguística diante do "ensino". E também são apontados alguns direcionamentos para as práticas de "ensino" em sala de aula, que, apesar de, em alguma medida, se assemelharem ao que foi tratado por Lobato (2003), se mostram uma evolução dos estudos linguísticos no direcionamento das práticas pedagógicas para o ensino de língua materna.

\subsection{Contribuições Dos Pressupostos Gerativistas Para A Educação Em Língua Materna - Silva (2013)}

Silva (2013) pretende estabelecer uma aproximação entre os pressupostos gerativistas e o ensino de língua portuguesa e verificar de que forma conceitos como, Aquisição de Linguagem, Gramática Universal (GU), Input e Argumento da Pobreza de Estímulo podem contribuir para avanço em relação ao "ensino" de língua materna.

No intuito de constatar de que maneira conceitos advindos da teoria gerativa podem auxiliar os professores a um maior entendimento dos fenômenos linguísticos, a autora, parte da análise de Chomsky (1981, 2006), Kato (2005), VanPatten (2003) para investigar de que maneira os pressupostos gerativistas podem ajudar a ampliar o entendimento de docentes sobre fenômenos como: as diferenças entre a fala e a escrita, aquisição de língua, princípios linguísticos, caracterização da linguagem humana e entendimento do papel dos dados de input e de output para a aprendizagem da escrita.

A partir das obras analisadas, a autora verifica que cabe ao professor de língua portuguesa ensinar ao aluno uma gramática que ele ainda não utiliza, o que Silva (2013) trata como GP, Gramática Padrão. Tal gramática é aprendida a partir de um input específico disponibilizado pelas práticas escolares, ou seja, diferente do que a criança teve contato antes de frequentar o ambiente escolar.

A partir do tratamento que é dado ao papel do input e do output, na proposta de VanPatten (2003), a autora questiona de que maneira o input deve ser oferecido ao aluno e que tipo de input seria esse para que ele adquira a gramática da língua escrita, ou a GP, uma vez que, pelo fato de os alunos saírem da escola despreparados para a produção textual, ou seja, não geram o output esperado, pode-se pressupor que a escola não esteja oferecendo o input necessário para tal aprendizagem, o que sugere que se repense as atuais metodologias de ensino. 
Silva (2013) se propõe a analisar oito obras que apresentam reflexões e orientações sobre educação em língua materna com o intuito de verificar de que forma são apresentadas as diferentes orientações e abordagens de ensino. A autora analisa as seguintes obras: Para uma nova gramática do português (Perini, 1986); O Ensino de português (Murrie, 1992); Língua e liberdade (Luft, 1993); Da fala para a escrita: atividades de retextualização (Marcurschi, 2001); Mas o que é mesmo "gramática”? (Franchi, 2006); Gramática: nunca mais - o ensino da língua padrão sem o estudo da gramática (Rocha, 2007); Gramática na escola (Neves, 2007) e Ensino de gramática: descrição e uso (Vieira \& Brandão, 2009).

No que diz respeito à adoção de teorias linguísticas, Silva (2013) aponta que a maioria das obras se baseia em mais de uma teoria, o que, segundo a autora, não se trata de algo condenável, mas que deve ser feito de maneira cautelosa. Porém pode-se observar na análise que alguns autores apresentam, em suas abordagens, conceitos que se aproximam dos pressupostos gerativistas e das noções de input e output de VanPatten (2003).

\subsubsection{Considerações sobre a leitura de Silva (2013)}

O estudo realizado tem um caráter inovador no sentido de compor um aparato bibliográfico que ainda é pioneiro na tentativa de relacionar os pressupostos gerativistas à questão no "ensino"/aprendizagem. Como se pode observar na leitura do texto, têm-se abertos caminhos para o entendimento da prática da educação em língua materna, mas que há ainda muitas questões a serem investigadas em relação a aspectos cognitivos da aprendizagem.

$\mathrm{Na}$ análise das obras, pode-se observar que elas abrangem de maneira consistente as discussões atuais concernentes às questões do "ensino" de língua portuguesa, mas ainda não oferecem propostas metodológicas sistematizadas para que realmente haja mudança nas práticas docentes.

O que este trabalho nos mostra é que muito se fala sobre a necessidade de inovação das práticas pedagógicas, mas pouco se tem de material disponível para que o professor utilize em sala de aula. Ao que parece, as abordagens acerca do conceito de linguagem ainda não estão bem sistematizadas, assim como as questões referentes à metodologia e prática de ensino. 
Em Silva (2013) podemos observar que o desenvolvimento de pesquisas científicas sobre o desenvolvimento da aprendizagem, ou seja, a aprendizagem em seus aspectos cognitivos, conciliado a técnicas de "ensino" que observem tais descobertas se mostram promissores na busca, não apenas pela renovação das práticas de ensino, mas de um ensino de língua realmente eficaz, contudo a autora parece considerar, em alguns momentos de sua pesquisa, a aprendizagem da gramática como algo semelhante ao ensino de uma L2, o que não faz parte das considerações deste trabalho.

\subsection{Considerações Parciais}

Este capítulo se dedicou a analisar os pressupostos gerativistas com base nos estudo de Chomsky (1950 e trabalhos subsequentes), no intuito de relacioná-los às questões de "ensino"/aprendizagem, além de estudos anteriores que também tratam de tal correlação, como as obras de Lobato (2003), Kato (2005), Pilati; Naves; Vicente \& Salles (2011), Vicente \& Pilati (2012), e Silva (2013).

As leituras e análises das obras em questão demonstram que os estudos gerativistas, atualmente, passaram a se preocupar também com as questões relacionadas ao "ensino" de língua materna, e nos confirmam que conceitos da Teoria Gerativa, como Aquisição de linguagem, Input, GU, Argumento da pobreza de estímulo, Criatividade, Competência e Desempenho são aplicáveis a tais questões.

Lobato (2003), ao propor uma metodologia baseada na intuição do aluno e que possuem níveis de análise que partem dos procedimentos de descoberta, eliciação, e técnica de resultados, trabalha claramente com os conceitos de Gramatica Universal e Competência. A autora apresenta de maneira clara e consistente com os pressupostos gerativistas, demonstrando como estes podem auxiliar na conscientização dos alunos de seus conhecimentos linguísticos internalizados. No entanto, Lobato (2003) se equivoca ao pressupor que os alunos têm intuição acerca de todas as estruturas gramaticais aprendidas na escola, o que as outras leituras já demonstram que não que verdade, pois a gramatica padrão, que o ensino formal objetiva ensinar, apresenta estruturas que não correspondem àquelas presentes na fala dos alunos.

Em Kato (2005) verificam-se as questões relacionadas à Aquisição de linguagem e o acesso à $G U$. A autora, ao discutir a semelhança do tratamento dado ao ensino de gramática e à aprendizagem de uma L2, nos demonstra que muito do que é aprendido 
em ambiente escolar sobre a língua materna não pertence à gramática internalizada pelo aluno, fato este de sugere tal discussão acerca das semelhanças com a L2. No entanto, como discutido anteriormente, verifica-se que a gramática padrão não se faz uma gramática nuclear, uma G2 na abordagem da autora, mas sim uma periferia marcada que acessa a G1 e, principalmente, a GU para organizar seus parâmetros. O fato de a gramática padrão acabar por se tornar um conjunto de regras aleatórias, como se refere a autora, acaba por ser mais um fator que demonstra a ineficiência do "ensino" da língua portuguesa no Brasil.

Pilati; Naves; Vicente \& Salles (2011) e Vicente \& Pilati (2012) se mostram um avanço dos estudos gerativistas no que diz respeito à educação. Enquanto Pilati; Naves; Vicente \& Salles (2011) trazem o foco de seu trabalho para o que chamam de educação linguística, Vicente \& Pilati (2012) refletem sobre o uso da palavra "ensino" com relação às práticas pedagógicas realizadas na aprendizagem da gramática padrão e ressaltam o papel da Competência do aluno como ponto de partida para as metodologias de "ensino".

Ambos os trabalhos, Pilati; Naves; Vicente \& Salles (2011) e Vicente \& Pilati (2012), se dedicam, em parte, a fazer uma análise dos Parâmetros Curriculares Nacionais. Pilati; Naves; Vicente \& Salles (2011) apontam que os PCN's não trazem um tratamento específico com relação às metodologias a serem adotadas no "ensino" de língua portuguesa. Já o trabalho de Vicente \& Pilati (2012) nos mostra que a redação dos PCN's sofre a influência de diferentes correntes linguísticas, não apresentando, portanto, uma concepção sistematizada do que seria linguagem.

Por fim, a dissertação de Silva (2013) destaca a importância do input e da criatividade para o trabalho realizado em sala de aula por parte do professor. Com base nos trabalho de VanPatten (2003) e Kato (2005) demonstra a importância de se oferecer um input diferenciado e previamente selecionado para o desenvolvimento da escrita pelos alunos, uma vez que, como demonstra Kato (2005) os alunos possuem intuição e, com isso, criatividade em relação a sua língua materna, mas algumas estruturas que são ensinadas na escola não estão presentes no conhecimento internalizado por estes, ou seja, em sua G1, o que reforça a necessidade de um input selecionado e organizado para o fim que deseja alcançar nas práticas pedagógicas.

Observou-se que há uma preocupação de diferentes correntes dos estudos linguísticos com relação ao componente curricular Língua Portuguesa e que essas questões ganham cada vez mais espaço nos estudos gerativistas. No entanto, a questão 
metodológica, apesar de estar sendo discutida nos trabalhos analisados, ainda não se apresenta de maneira clara e sistematizada, mas se mostra um projeto em construção. Ao que parece, o desenvolvimento das pesquisas acerca da construção do conhecimento, da Faculdade da Linguagem e da aquisição de L1 são parte importante no processo de elaboração de metodologias que tornem a aprendizagem da gramática padrão, de fato, efetiva. 


\section{Capítulo 2. Pesquisas sobre a construção do conhecimento e o desenvolvimento de metodologias e ensino}

Este capítulo tem o objetivo de apresentar estudos sobre: a) a aprendizagem em geral (ou seja, estudos sobre como a aprendizagem ocorre), estudos sobre abordagens de ensino (isto é, como propiciar a aprendizagem), e, por fim, c) serão analisadas duas propostas de métodos de ensino de língua portuguesa, com base na revisão bibliográfica feita em (a) e (b). Em relação à aprendizagem será apresentada a resenha da obra Como as pessoas aprendem: cérebro, mente e escola (2010), organizada pelo Comitê de Desenvolvimento da Ciência e da Aprendizagem. Já quanto às reflexões sobre abordagem, métodos e técnicas, serão apresentadas as resenhas de Richards \& Rodgers (2001) e Fink (2003). Para tratar do "ensino" de língua portuguesa de maneira mais específica, serão analisadas as diretrizes adotadas para o ensino de língua portuguesa no Brasil e em Portugal, os PCN's (1997) e o Guião de Implementação do Programa de Português do Ensino Básico (2011) respectivamente.

Diferentemente do capítulo anterior, as obras não serão apresentadas seguindo o critério cronológico, mas, sim, sob o critério temático.

\subsection{Como as pessoas aprendem: cérebro, mente e escola (2010)}

Como as pessoas aprendem: cérebro, mente e escola (2010) é resultado de um conjunto de pesquisas sobre processos de aprendizagem, realizado pelo Conselho Nacional de Pesquisa dos Estados Unidos. O livro busca apresentar "um entendimento mais amplo acerca da estrutura do conhecimento; do raciocínio; dos fundamentos iniciais da aprendizagem; da metacognição e de como o pensamento simbólico emerge da cultura do aprendiz" (p. 32). A obra visa contribuir para uma mudança tanto da teoria como da prática pedagógica.

O primeiro capítulo da obra, intitulado Aprendizagem: da especulação à ciência, afirma que houve uma revolução no estudo da mente, ocorrida por volta dos anos 50 . Tal revolução se deu em oposição ao Behaviorismo ${ }^{1}$ e fez com que a aprendizagem deixasse de ser relacionada ao comportamento e passasse a ser considerada como

\footnotetext{
${ }^{1}$ O Behaviorismo nasceu durante a segunda metade do século XX, sob o impulso de seu fundador J. B. Watson. Segundo tal teoria, o condicionamento dos organismos é possível graças à manipulação cuidadosa de contingências que possam exercer um efeito reforçador ou enfraquecedor sobre os comportamentos. (Gauthier \& Tardif, 2010, p. 380 - 381)
} 
"compreensão". Sendo assim, passou-se a se valorizar mais o entendimento que a memória. Para essa nova linha de pensamento, o conhecimento não deve ser uma lista de fatos a serem decorados, e, sim, conhecimento utilizável, ou seja, organizado em torno de conceitos importantes que possam ser resgatados e aplicados à resolução de situações-problemas.

O foco nos processos de conhecimento revelou que "as pessoas elaboram o novo conceito e o entendimento com base no que já sabem e naquilo que acreditam" (Como as pessoas aprendem: cérebro, mente e escola, 2010, p. 27) o que, no ensino, se reflete em uma nova postura dos professores em relação a seus alunos, pois aqueles devem prestar atenção aos entendimentos incompletos, às crenças falsas e às interpretações ingênuas dos conceitos que os aprendizes trazem sobre o assunto, já que os conhecimentos adquiridos, se associados aos conhecimentos prévios de forma equivocada, podem comprometer a compreensão do aprendiz.

O processo de construção do conhecimento passou a ser voltado para o aprendizado ativo. Sob essa concepção, o papel do professor é ajudar as pessoas a assumirem o controle de sua própria aprendizagem. Um conceito importante relacionado à construção do conhecimento é o de metacognição: que consiste em ser capaz de monitorar seus níveis de domínio e compreensão dos assuntos e, com isso, poder prever o próprio desempenho em diversas tarefas. Muitas vezes, a metacognição toma a forma de uma conversa interior. Envolve também práticas que focalizam a criação de sentido, a auto avaliação e a reflexão sobre o que precisa ser melhorado.

Os estudos sobre os fundamentos da aprendizagem geraram, portanto, três principais descobertas: i). as ideias preconcebidas dos alunos devem ser consideradas para que sua compreensão acerca dos novos conceitos não seja comprometida; ii) o desenvolvimento de competências em uma área depende da construção de um base sólida de conhecimento factual, organizado de forma a facilitar sua recuperação e aplicação e iii) uma abordagem metacognitiva pode ajudar os estudantes a assumirem o controle de sua própria aprendizagem.

Em linhas gerais, pode-se inferir que tais descobertas acarretam diferentes consequências para a educação. Primeiramente, deve-se conceber uma preparação diferenciada dos professores, pois estes devem trabalhar com a compreensão preexistente dos alunos, devem proporcionar uma base sólida de conhecimento factual, ou seja, tratar os assuntos em profundidade, e integrar o ensino de habilidades metacognitivas às diversas áreas. Deve-se ainda ter escolas e salas de aulas centradas 
no aprendiz, prestar atenção ao que é ensinado, por que é ensinado e como se revela a competência ou habilidade em determinada área, além de realizar avaliações idealizadas para tornar visível o raciocínio dos alunos. Não se pode deixar de considerar também que a aprendizagem é influenciada de maneira fundamental pelo contexto em que acontece.

Na obra, busca-se mostrar a importância de se entender o que é competência para, então, entender a natureza do raciocínio e da solução de problemas. No livro, isso é feito com base na comparação do comportamento de principiantes e especialistas diante de situações-problema. O raciocínio dos especialistas se dá a partir da percepção de padrões significativos de informação, e "sua capacidade de identificar tipos de problemas advém do desenvolvimento de estruturas ou esquemas conceituais organizados que orientam o modo de representar e entender o problema" (p. 54). Seus conhecimentos refletem uma compreensão profunda dos assuntos e contextos de aplicabilidade, especialistas organizam seu conhecimento em torno de conceitos essenciais que orientam seu raciocínio, enquanto que principiantes o fazem com base em atributos superficiais e, com isso, não conseguem avaliar a situação de maneira adequada, o que dificulta a aplicação do conhecimento, ou seja, a transformação de conhecimento factual em conhecimento utilizável, uma vez que a superficialidade permeia tanto seu raciocínio quanto o seu domínio do assunto de determinada área. Já os especialistas recuperam informações relevantes com pouco esforço, uma vez que estas incluem uma especificação dos contextos em que são úteis (conhecimento utilizável), e conseguem abordar novas situações de maneira flexível, o que é resultado da metacognição, ou seja, da capacidade de se utilizar o que se aprende, mas também de questionar os níveis atuais de competência para ir além deles.

No entanto é ressaltado que, apesar disso, especialistas não necessariamente são bons professores, uma vez que a competência pode prejudicar o ensino, pois estes esquecem o que é fácil e o que é difícil para os estudantes. É nesse ponto que entra a distinção entre conhecimento de conteúdo, isto é, a competência em uma disciplina, e conhecimento de conteúdo pedagógico, que fundamenta o ensino efetivo e se traduz em um conjunto de estratégias de ensino que diferem de uma disciplina para outra. É o tipo de conhecimento que os professores precisam aprender para se tornarem mais eficazes.

Tais considerações fazem com que se passe a pensar o ensino baseado no desenvolvimento das capacidades do estudante de identificar padrões significativos de informação, uma vez que são estes que irão fornecer as condições que desencadeiam o 
acesso ao conhecimento relevante para as tarefas a serem executadas. Ressalta-se também a necessidade de se ter currículos organizados de modo que conduzam à compreensão conceitual, já que normalmente há pouco espaço para o desenvolvimento de ideias importantes e organizadas, de se desenvolverem atividades baseadas na resolução de situações-problema, como uma maneira de ajudar os estudantes a aprender condições de aplicabilidade, com elas eles podem aprender quando, onde e por que usar o conhecimento que estão aprendendo, ou seja, o conhecimento deve ser "condicionalizado" a fim de ser recuperado quando necessário, caso contrário, este permanece inerte. As informações relevantes devem ser seletivas e facilmente recuperadas, e isso se dá, acima de tudo, com o desenvolvimento da metacognição, um conceito importante que acaba por ser fazer também uma habilidade imprescindível para a aprendizagem formal de língua materna.

Coloca-se, como um dos objetivos principais da aprendizagem, a transferência, ou seja, a capacidade de se ter acesso às informações para um amplo conjunto de propósitos. É necessário desenvolver características da competência adaptativa. A capacidade de transferência ajuda a compor o conceito de conhecimento utilizável. De acordo com o livro, os processos de aprendizagem e transferência do aprendizado são fundamentais para compreender como as pessoas desenvolvem competências significativas, uma vez que é na aplicação do conhecimento que se pode observar de que maneira este foi desenvolvido pelo aprendiz, e, com isso, mensurar o papel desempenhado pela transferência na avaliação da qualidade das experiências de aprendizagem, uma vez que, segundo o texto, toda nova aprendizagem envolve transferência.

Junto ao conceito de conhecimento utilizável, o livro apresenta característicaschave da aprendizagem e da transferência que apresentam implicações importantes para a educação:

a) A aprendizagem inicial é necessária para a transferência - ou seja, a aprendizagem se dá por etapas e a aprendizagem inicial é determinante no desenvolvimento da competência e da capacidade de transferir.

b) As representações abstratas do conhecimento podem ajudar a promover a transferência - a capacidade de transferência depende do grau em que as pessoas aprendem com compreensão.

c) Transferência é um processo ativo e dinâmico - os aprendizes controlam a aprendizagem, avaliando situações-problemas e estratégias de solução. É 
apresentado um contraste em relação à transferência quando esta se dá de maneira ativa e quando esta se apresenta de forma passiva. De acordo com a obra, a transferência ativa é um processo dinâmico, que exige que os aprendizes escolham e avaliem estratégias, considerem recursos e recebam feedback. Enquanto que a transferência passiva é capacidade dos aprendizes de resolver um conjunto de problemas de transferência logo depois de se envolverem em uma tarefa inicial de aprendizagem, ou seja, esta se dá de maneira mecânica, baseada na repetição, enquanto aquela envolve uma análise da situação e elaboração de estratégias.

d) A aprendizagem de algo novo envolve a transferência com base na aprendizagem prévia - um dos elementos que influenciam a transferência bemsucedida envolve o grau de domínio que se tem do assunto original. O que gera consequências para o projeto de instrução, que deve ser direcionado para que o conhecimento prévio contribua de forma positiva na aprendizagem, uma vez que este pode prejudicá-la, pois é capaz gerar barreiras para a aprendizagem ou erro na interpretação dos novos dados.

Conhecimento prévio inclui o tipo de conhecimento que os aprendizes adquirem em virtude de seus papéis sociais. Esse conhecimento cultural pode, às vezes, apoiar a aprendizagem das crianças nas escolas e, outras vezes, entrar em conflito com ela.

De um modo geral, pode-se constatar que a capacidade de transferência depende do grau de compreensão envolvido no processo de aprendizagem em que as pessoas aprendem com compreensão. É necessário tempo para investigar conceitos básicos e estabelecer conexões com outras informações que os aprendizes já possuem. Além disso, é necessário que a instrução apresente princípios de organização significativos para gerarem a aprendizagem de conjuntos de fatores organizados que apresentam relações entre si. De acordo com as pesquisas, o entendimento de quando, onde e por que usar o novo conhecimento pode ser ampliado por meio do emprego de "casos contrastantes".

Uma característica apresentada como essencial para o desenvolvimento do conhecimento está na motivação para aprender. A tendência dos aprendizes de perseverar diante da dificuldade é muito influenciada pelo fato de serem ou "orientados para o desempenho" (mais preocupados em não errar do que em aprender), ou “orientados para a aprendizagem" (gostam de novos desafios). 
Outros fatores que influenciam a transferência e demonstram como as condições de aprendizagem então diretamente relacionadas à capacidade de transferência são:

- Contexto - ensinar em contextos múltiplos (abstrair as características relevantes dos conceitos e desenvolver uma representação flexível do conhecimento).

- Representações de problemas - representar com níveis mais elevados de abstração. Quanto maior o grau de abstração, maior a probabilidade de que a transferência se dê de forma positiva, assim como a observação de semelhanças e diferenças entre eventos distintos.

Como se pôde observar, a transferência é sempre resultado da relação entre o que é aprendido e o que é testado é uma espécie de sobreposição entre o domínio original do aprendizado e o novo domínio, sendo que esta pode requerer indução ou não. No entanto, os testes de transferência que utilizam a indução graduada fornecem uma análise mais refinada da aprendizagem e de seus efeitos sobre a transferência do que as avaliações simples e isoladas para verificar se houve ou não transferência.

A transferência pode ser melhorada com o desenvolvimento da metacognição. As abordagens metacognitivas de instrução demonstram aumentar o grau em que os estudantes transferem o que aprendem para novas situações sem necessidade de indução explícita. A transferência mais eficaz é resultado de um equilíbrio entre exemplos específicos e princípios gerais.

Com a mudança de paradigma acerca do ensino, em que se deixou de considerar a criança como uma tábula rasa e passou-se a valorizar o conhecimento prévio que ela utiliza nos processos de aprendizagem, tornou-se importante entender, de forma mais específica, como as crianças aprendem. Entender como se dá esse processo na criança se faz necessário para suavizar a transição desta para ambientes escolares formais.

Um papel extremamente importante a ser desempenhado pelos professores é o de ajudar seus alunos a relacionar as novas situações com situações mais familiares. $\mathrm{Na}$ discussão sobre o desempenho e a transferência competentes, constatou-se que o conhecimento apropriado a uma situação específica não é necessariamente acessado, apesar de ser relevante. Os professores devem ajudar os alunos a estabelecer conexões entre os diferentes aspectos de seu conhecimento, proporcionando estruturas de apoio para o desempenho da criança com atividades que: 
a) Despertem o interesse da criança pela tarefa;

b) Reduzam a quantidade de etapas necessárias para resolver um problema, simplificando a tarefa, de modo que a criança possa administrar os elementos do processo e identificar quando conseguiu cumprir as exigências da tarefa;

c) Mantenham criança no encalço do objetivo, motivando-a e orientando-a na atividade;

d) Assinalem os aspectos críticos das discrepâncias entre o que a criança produziu e a solução ideal;

e) Controlem a frustração e o risco na resolução do problema e

f) Demonstrem uma visão idealizada do ato realizado.

O que se constata no capítulo é que o conceito de desenvolvimento é decisivo para a compreensão das mudanças no pensamento infantil. $\mathrm{O}$ entendimento inicial das crianças a respeito do mundo perceptivo e físico pode servir de arranque para o processo de aprendizagem e até torná-lo possível. O que os estudos indicaram é que as crianças carecem de conhecimento e experiência, mas não da capacidade de raciocínio.

\subsubsection{Considerações sobre a leitura de Como as pessoas aprendem: cérebro, mente $e$ escola (2010)}

Os estudos demonstram que as pesquisas destinadas a conhecer o funcionamento da mente e, consequentemente, o desenvolvimento da aprendizagem nos trazem um novo conceito do que se considera conhecimento, além de demonstrar de que maneira ele se desenvolve e como essas descobertas interferem nas metodologias de "ensino". No entanto, antes de tudo, é importante ressaltar que a obra não se refere à aprendizagem de línguas de maneira específica, mas trata da aprendizagem de um modo geral.

Como se observa na obra, o conhecimento passa a ser considerado conhecimento utilizável, ou seja, dominar conteúdos deixa de ser simplesmente armazenar informações e passa a ser a capacidade de aplicar a informação em situações-problema que a requisite. Tal mudança conceitual acaba por refletir significativamente no que se espera das metodologias aplicadas em sala de aula, agora estas não podem encarar a aprendizagem como um processo passivo e nem podem se resumir apenas a uma 
"taxonomia", cabe a elas agora desenvolver a metacognição. A partir disso, se torna importante ressaltar a diferença que a obra estabelece entre Conhecimento de conteúdo e Conhecimento de disciplina. Conhecimento de conteúdo diz respeito à competência, em qualquer área do conhecimento, a ser desenvolvida no aluno, enquanto que o Conhecimento de disciplina está relacionado às estratégias de ensino, ou seja, enquanto aquele deve pertencer ao aluno, este de estar presente na formação dos professores.

O conceito de metacognição acaba por se assemelhar ao que aparece nos estudos de Pilati; Naves; Vicente \& Salles (2011) e Vicente \& Pilati (2012) quando as autoras tratam da questão de o aluno se tornar consciente do conhecimento que já possuem sobre a língua que falam. $\mathrm{O}$ fato de o aluno estar ativo no processo de aprendizagem está diretamente relacionado ao desenvolvimento da metacognição, pois é com ela que ele terá controle sobre a aprendizagem tanto no momento de conhecer novos conteúdos, quanto no momento de aplicá-los e, no que se refere ao idioma, é o desenvolvimento dela que permitirá ao aluno manipular conscientemente as estruturas de sua língua materna de acordo com o contexto em que está inserido, tanto socialmente quanto em relação à modalidade fala/escrita.

O livro sugere uma metodologia de ensino baseada em desenvolver nos aprendizes a capacidade de identificar padrões e de solucionar situações-problema. Segundo a obra, o aprendiz, a partir do momento que consegue identificar um padrão, acaba por selecionar adequadamente o conhecimento a ser aplicado a tal situação, tornando-o, assim, um Conhecimento Utilizável, e tal habilidade é desenvolvida com atividades em que se devem resolver situações-problema, pois, avaliando as situações, o aluno saberá se tem conhecimento para resolvê-la, e caso o tenha, saberá como aplicalo, a isso é dado o nome de Competência Significativa, a capacidade de transferência que, sendo o principal meio de avaliação do progresso da aprendizagem, vai medir tal progresso relacionando o que é aprendido com o que é testado.

Há a necessidade de mudar a finalidade das atividades aplicadas em sala de aula, os alunos, como é abordado na obra, não devem ser orientados para o desempenho, ou seja, o objetivo da tarefa não pode ser obter o menor número de erros possível, mas sim devem encarar as tarefas como novos desafios, isto é, serem orientados para a aprendizagem. Quanto à aprendizagem da gramática padrão, podemos fazer uma analogia com relação a uma metodologia meramente prescritiva, orientada para o desempenho, e uma metodologia que visa a desenvolver o conhecimento que o aluno já tem internalizado, orientada para a aprendizagem. 
A obra, ainda que não estabeleça uma relação direta com os pressupostos gerativistas, trabalha com um conceito muito importante para a teoria, a competência. Em Como as pessoas aprendem: cérebro, mente e escola (2010), o conhecimento préexistente é um dos determinantes dos rumos que tomará a construção do conhecimento e, por isso, deve ser levado em consideração nas práticas pedagógicas independentemente do conteúdo a ser abordado. Esse conhecimento pré-existente pode ser encarado na Teoria Gerativa como a Competência Linguística. Todo aluno inicia na escola com um conhecimento pré-existente do idioma que fala e o que será aprendido por ele na escola relacionar-se-á diretamente com esse conhecimento, o que nos retoma ao trabalho de Vicente \& Pilati (2012), que ressalta a necessidade de considerar, em qualquer prática pedagógica para o "ensino" de língua, a Competência do aluno. Tendo isso em vista, vê-se a importância da metodologia de Lobato (2003), aprimorada pelas autoras, o procedimento de descoberta, técnicas de eliciação e técnicas de resultados. Com relação à técnica de resultados, essa se assemelharia ao que o Como as pessoas aprendem: cérebro, mente e escola (2010) chama de capacidade de transferência.

\subsection{Approaches and Methods in Language Teaching - Richards \& Rodgers (2001)}

De acordo com Richards \& Rodgers (2001), as seguintes reflexões que devem ser levadas na escolha e desenvolvimento da metodologia a ser utilizada em classe:

a. Quais são as metas do ensino de língua?

b. Qual é a natureza básica da língua, e como isso afetará os métodos de ensino?

c. Quais são os princípios para a seleção da linguagem significativa no ensino de língua?

d. Quais os princípios de organização, sequenciamento e apresentação que melhor facilitem a aprendizagem?

e. Qual processo os aprendizes usam no domínio da língua, e que pode ser incorporado ao método?

f. Quais técnicas de ensino e atividades funcionam melhor e sob quais circunstâncias? 
Segundo a obra, três visões teóricas em relação à língua e à natureza da linguagem influenciam as abordagens e métodos atuais de ensino de língua. São elas:

- Estruturalista - considera a língua como um sistema de estrutura que relaciona elementos para gerar significados.

- Funcionalismo - considera a língua como um veículo para a expressão de significados funcionais.

- Interacionismo - considera a língua como um veículo para a realização de interação interpessoal e para a performance de transações sociais entre indivíduos.

Com base nos estudos de Antony (1963: 63-67), Richards \& Rodgers (2001) apontam que o arranjo que combina abordagem, método e técnica é hierárquico. A chave da organização é que as técnicas realizam o método, o qual é consistente com uma abordagem. Para organizar esse arranjo, são apontados os seguintes conceitos:

1. Abordagem - é um conjunto de hipóteses correlatas que tratam da natureza do ensino e aprendizagem de línguas. Abordagem é axiomático. Ela descreve a natureza do assunto a ser abordado.

2. Método - é um plano global para a apresentação ordenada do material sobre a língua. Nenhuma parte dele contradiz, estando tudo baseado, na abordagem escolhida. Abordagem é axiomático, método é processual. Dentro de uma abordagem podem existir muitos métodos.

3. Técnica - é implementada, é o que de fato acontece em sala de aula, um truque especial, estratégia, ou artifício usado para realizar um objetivo imediato. Técnicas devem ser compatíveis com um método, e, consequentemente, exigem harmonia com uma abordagem.

Os autores ainda trazem para o sistema instrucional o conceito de Design, que, segundo eles, considera:

a) Quais são os objetivos do método;

b) Como a linguagem significativa é selecionada e organizada no método; 
c) Os tipos de tarefas de aprendizagem e atividades de ensino que o método preconiza;

d) Os papéis dos aprendizes;

e) Os papéis dos professores;

f) O papel do material instrucional.

O que se observa na utilização desse arranjo para o ensino é que o método pode ser descrito a partir de questões que identificam os níveis de: abordagem, design e procedimento, os quais se utilizam dos princípios teóricos e as práticas que derivam deles.

\subsubsection{Considerações sobre a leitura de Richards \& Rodgers (2001)}

Os apontamentos de Richards \& Rodgers (2001) reforçam o que se aborda no livro Como as pessoas aprendem: cérebro, mente e escola (2010) no que diz respeito à necessidade de considerar de que maneira a aprendizagem acontece para que se elabore metodologias de ensino que sejam capazes de desenvolvê-la.

Com um olhar mais voltado para o desenvolvimento do que o os autores chamam de Design Instrucional, deixa-se claro que as práticas pedagógicas devem ser muito bem pensadas e arquitetadas antes de serem levadas para a sala de aula. Não apenas no que se refere ao "planejamento de aula", mas, sim, algo muito maior: tratar o conteúdo dentro de uma abordagem baseada em uma teoria sobre língua, que combina uma seleção de metodologias que se realizam na técnica a ser aplicada nas aulas.

\subsection{Creating Significant Learning Experiences - Fink (2003)}

A obra de Fink (2003), Creating Significant Learning Experiences, faz um estudo sobre a aprendizagem significativa, ressaltando a importância das escolhas metodológicas para que se criem, em sala de aula, experiências de aprendizagem que alcancem os objetivos das práticas pedagógicas. Fink (2003) aponta dados que demonstram o quanto a escolha da metodologia para o ensino prescinde de uma reflexão acerca dos objetivos da aprendizagem. De acordo com o autor, pesquisas revelam que 
entre $73 \%$ e $83 \%$ dos professores escolhem a leitura como método básico para a instrução. No entanto a leitura tem efeitos limitados no que diz respeito a:

- Reter informações posteriormente.

- Desenvolver habilidades para transferir o conhecimento para outros contextos.

- Desenvolver habilidades de questionar ou solucionar problemas.

- Motivação para uma aprendizagem mais aprofundada.

O ensino deve ter como um dos objetivos criar experiências de aprendizagem significativa e com isso alcançar os seguintes resultados: i) gerar nos estudantes uma mudança significativa e duradoura e ii) fazer com que a aprendizagem tenha valor na vida dos estudantes.

Com base nos estudos de Bloom (1956), que tratam do domínio cognitivo, o autor aponta que a nomenclatura cognitiva consiste em seis tipos de arranjos da aprendizagem em sequência hierárquica: Avaliação; Síntese; Análise; Aplicação; Compreensão e Conhecimento (habilidade para recuperar informações).

No entanto, o autor complementa tal arranjo reconhecendo que também há questões outras importantes para o desenvolvimento da aprendizagem significativa, como: Aprender a como aprender; Conhecimento profundo; Integração; Dimensão humana e Reconhecer a importância do que é aprendido.

Além disso, com os estudos de Robert Sternberg (1989), o autor destaca a importância de uma visão tripla em relação ao pensamento, o que ajuda os estudantes a aprender a pensar com mais efetividade. Tais dimensões se referem ao:

- Pensamento crítico - entendimento conceitual para avaliar a qualidade das interpretações, explicações e predições.

- Pensamento criativo - utilização de novas maneiras de responder questões, desenvolvimento de novas perspectivas sobre o fenômeno estudado, desenvolver novas soluções para os problemas. Criar novas ideias, novos jeitos de fazer as coisas.

- Pensamento prático - a aplicação do conhecimento em contextos diversificados. 


\subsubsection{Considerações sobre a leitura de Fink (2003)}

Fink (2003) demonstra em sua pesquisa alguns aspectos que devem ser levados em consideração para que as práticas pedagógicas permitam a que ocorra a aprendizagem significativa, entre eles têm-se: aprender a como aprender, conhecimento profundo, aplicação, integração e reconhecimento da importância do que é aprendido. Entretanto, é possível notar que alguns desses conceitos se assemelham ao que é apresentado nos estudos presentes no livro Como as pessoas aprendem: cérebro, mente e escola (2010). Quando Fink (2003) trata da questão de aprender a aprender, vê se claramente o conceito de metacognição, assim como também se pode relacionar o conhecimento profundo que o autor aborda ao conhecimento que o livro Como as pessoas aprendem: cérebro, mente e escola (2010) diz ser o conhecimento dos “especialistas”. Os conceitos de Aplicação e Integração, presentes na obra do autor, estão diretamente relacionadas à capacidade de transferência do conhecimento e o reconhecimento da importância do que é aprendido corrobora para tornar o conhecimento um Conhecimento Utilizável.

\subsection{Parâmetros Curriculares Nacionais - Brasil (1997)}

Os Parâmetros Curriculares Nacionais é o documento adotado pelo Brasil para servir de referência e consulta no que diz respeito ao tratamento didático proposto para cada componente curricular. Sua intenção é contribuir para que se alcancem as finalidades do ensino exigidas pelas práticas sociais.

Nos PCN's a perspectiva linguística adotada é o sócio-interacionismo, teoria da aprendizagem desenvolvida por Lev Vygotsky, a qual considera que a interação com o outro e com o meio tem papel determinante para o desenvolvimento sócio-cognitivo. Com base nessa abordagem, os PCN's destacam a natureza interativa da linguagem, e tomam a comunicação como a base das ações, sendo também entendida como um processo de construção de significados em que o sujeito interage socialmente, "usando a língua como instrumento que o define como pessoa entre pessoas" (p. 17). A partir disso, o estudo da gramática se torna uma mera estratégia para 
compreensão/interpretação/produção de textos e a literatura integrando-se à área da leitura.

O documento também faz críticas a práticas educativas desvinculadas da realidade e dos interesses dos alunos; critica também a descontextualização do conteúdo, o uso inadequado da leitura e produção de textos: excessiva escolarização dessas atividades, a excessiva valorização da gramática normativa e a história da literatura sendo o foco da compreensão do texto e na grande maioria dos casos tendo-se o conceito de texto literário bastante discutível por ter se tornado um tanto quanto arbitrária a classificação do que de fato é literatura.

Buscando o desenvolvimento de uma adequação da linguagem a situações de uso, os Parâmetros Curriculares Nacionais estabelecem competências e habilidades a serem alcançadas no Ensino Médio em relação à compreensão de língua portuguesa. De acordo com o documento, estas se categorizam em relação à:

a) representação e comunicação, que se resumem basicamente em um confrontamento de pontos de vista sobre as diferentes manifestações da linguagem verbal, uma compreensão e uso da língua portuguesa como geradora de significação e organização do mundo e da própria identidade e uma aplicação das tecnologias de comunicação e da informação;

b) investigação e compreensão, que seria a análise dos recursos expressivos da linguagem verbal de acordo com as condições de produção e recepção, a recuperação, pelo estudo do texto literário, da cultura de vários lugares e várias épocas e a articulação das diferenças e semelhanças entre a língua oral e escrita;

c) contextualização sócio-cultural, que visa considerar a língua portuguesa legitimadora de acordos e condutas sociais e como representação simbólica de experiências humanas e entender os impactos das tecnologias da comunicação, em especial da língua escrita na vida social.

Como se pode ver, os conteúdos tradicionais foram incorporados por uma perspectiva maior, que é a linguagem, entendida como um espaço dialógico, em que os locutores se comunicam. Aqui, o sujeito é entendido como um texto que constrói textos.

Essa atual abordagem no ensino da língua visa promover o aluno à figura de sujeito ativo no processo de aprendizagem, além de reposicionar o professor nessa interação, passando, também, a considerar o meio nesse processo. Também valoriza o desenvolvimento da competência linguística do aluno, tendo como foco o texto. A 
gramática é considerada uma mediadora que se revela a partir do momento em que o aluno começa a ter um maior domínio de manipulação da linguagem, os conteúdos de língua portuguesa são organizados sob o eixo USO - REFLEXÃO - USO.

O objetivo dos PCNs é fazer do aluno um sujeito ativo na sociedade, alguém que é capaz de se posicionar nos domínios sociais com maturidade linguística e expressiva, que saiba manipular os recursos gramaticais que a língua oferece, mas que seja tolerante quanto às variedades da língua e saiba usá-las como um recurso expressivo, assim como usa a norma padrão.

O domínio da língua, oral e escrita, é fundamental para a participação social efetiva, pois é por meio dela que o homem se comunica, tem acesso à informação, expressa e defende pontos de vista, partilha ou constrói visões de mundo, produz conhecimento. Por isso, ao ensiná-la, a escola tem a responsabilidade de garantir a todos os seus alunos o acesso aos saberes linguísticos, necessários para o exercício da cidadania, direito inalienável de todos. (Parâmetros Curriculares Nacionais, 1997, p. 11)

\subsubsection{Considerações sobre a leitura dos PCN's (1997)}

Os PCN's não tratam de uma metodologia de ensino e muito menos apontam uma metodologia a ser adotada, na verdade, seu objetivo é apenas traçar diretrizes para a educação no país, são um ponto de partida para orientar escolas e professores em relação ao ensino.

No entanto, o problema se encontra justamente na efetivação dessa nova abordagem do ensino, uma vez que se fala muito sobre ela, mas não se testemunha sua prática. Os motivos para isso são inúmeros: professores não têm uma formação acadêmica condizente com o que se propõe nos PCN's, os livros didáticos continuam valorizando excessivamente a gramática normativa, as atividades de leitura e escrita se mantêm excessivamente escolarizadas, isto é, fogem às situações cotidiana de uso da escrita por parte dos alunos, dentre outras coisas.

O trabalho de Pilati; Naves; Vicente \& Salles (2011) apontou o fato de os PCN's não tratarem de metodologias específicas para o "ensino" de língua. No que diz respeito à realização das atividades, o documento diz que as atividades gramaticais devem estar relacionadas às práticas textuais, no entanto não há orientações a respeito de como isso deve ser feito. Não há formas práticas para que os objetivos ali propostos sejam alcançados. Falta-lhe também menção direta ao ensino de gramática, na verdade, os 
PCN's apenas fazem críticas às práticas de ensino tradicionais, permitindo a inferência de que o "ensino" de gramática está perdendo espaço na sala de aula.

Faz-se necessário operacionalizar as orientações presentes nos PCN's, uma vez que esse é fonte de consulta, reflexão e debate. Ao tratar das atividades, faz-se apenas uma diferenciação entre atividades epilinguísticas, aquelas que "brincam" com a linguagem, e as metalinguísticas, as que descrevem a língua. Sem apresentar exemplos específicos, diz que as atividades devem sistematizar a linguagem interiorizada pelo aluno, incentivando sua verbalização, assim como o domínio de outras variedades linguísticas utilizadas nas diferentes esferas sociais. Os PCN's consideram que tanto o ponto de partida quanto a finalidade do ensino é a produção/ recepção de discursos, ou seja, direciona o "ensino" à ampliação da competência discursiva sem tratar da competência linguística como algo de igual importância.

O documento traz o texto como a unidade básica do ensino e considera os saberes linguísticos necessários ao exercício da cidadania, além de atribuir o "fracasso" escolar à ineficácia da aprendizagem da leitura e da escrita. Vê-se que os PCN's direcionam as práticas pedagógicas a um trabalho voltado para a análise elaboração de textos como prática social. Entretanto, é importante relembrar que Fink (2003) observa que as atividades voltadas apenas para a leitura têm efeitos limitados na aprendizagem.

Os Parâmetros Curriculares nacionais tratam a gramática como "o conhecimento que o falante tem de sua língua" (p. 27), o que é considerado gramática internalizada na literatura linguística. De acordo com Lobato (2003), os PCN's decretam o fim do ensino gramatical como este vem sendo praticado até então, no entanto a autora frisa que a presença da gramática no ensino é necessária, mas sob uma nova percepção. Os professores precisam assimilar o conceito de gramática como algo biológico, mudando, consequentemente, o conteúdo programático.

Organizando os Parâmetros Curriculares Nacionais dentro do arranjo hierárquico proposto por Richards \& Rodgers (2001) observamos como é falho o direcionamento das práticas pedagógicas proposto no documento:

- Abordagem: Sociointeracionista, sendo assim, considera a língua "um sistema de signos histórico e social que possibilita ao homem significar o mundo e a realidade". (Parâmetros Curriculares Nacionais, 1997, p 17)

- Método: Não apresenta uma combinação de métodos, mas apenas o texto como unidade básica de ensino. 
- Técnica: Não há orientação com relação às técnicas a serem utilizadas.

Já ao estabelecer uma relação entre os PCN's e os conceitos apresentados no livro Como as pessoas aprendem: cérebro, mente e escola (2010), conseguimos observar o progresso das diretrizes para o ensino, pois, quando estas trazem o foco para as práticas sociais, demonstram-se compatíveis com o conceito de "Conhecimento Utilizável" apresentado no livro, além de que considerar o aluno como um elemento ativo no processo de aprendizagem. A sala de aula não deve ser um espaço para o "ensino", mas, sim, um local de aprendizagem em que professor é tido como mediador na tríade aluno, conhecimento e ensino. Os PCN's passam a considerar os conhecimentos prévios dos alunos no processo de aprendizagem. Observa-se, porém, que o documento ainda prioriza o uso da língua e não a reflexão sobre essa, além de pautar o ensino nas variedades e não nos padrões, regularidades, que a língua apresenta.

Como se observou na análise, os estudos acerca da aprendizagem trouxeram um grande avanço nas diretrizes adotadas para o ensino de Língua Portuguesa. Este agora apresenta objetivos voltados ao uso do idioma e não apenas ao domínio da metalinguagem, reestabelecendo o papel do professor e do aluno no processo de ensinoaprendizagem.

No entanto, se pensarmos que esse é o único objeto de consulta e orientação de milhares de professores, percebemos a necessidade de diretrizes que apresentem um arranjo melhor sistematizado, ou seja, que de fato consiga combinar, de maneira eficiente, abordagem, método e técnica em um design instrucional.

Ao analisar os documentos, também sentimos a falta de orientação em relação à elaboração das atividades gramaticais, ou seja, de maneiras de operacionalizar as diretrizes apresentadas.

\subsection{Guião de Implementação do Programa de Português do Ensino Básico - Costa et al. (2011)}

O Guião de Implementação do Programa de Português do Ensino Básico (2011), de Ana Santiago, Assunção Caldeira Cabral, Filomena Viegas e João Costa, é um programa de português para o ensino básico implementado em Portugal. O documento pretende ser um instrumento auxiliar para o docente. No guia, trabalha-se, em particular, 
a competência Conhecimento Explícito da Língua, explicitando o papel e a natureza dessa competência nos programas, o que significa ensinar gramática numa perspectiva articulada com outras competências e verificar quais as implicações metodológicas dessa concepção do ensino da gramática para o trabalho de didática da língua.

Esse novo documento assume, portanto, um trabalho sobre Conhecimento Explícito da Língua enquanto competência autônoma (com um estatuto idêntico ao das outras competências) e não apenas instrumental e transversal, além de um trabalho sobre Conhecimento Explícito da Língua e não sobre Funcionamento da Língua.

Para entender essa nova postura, é necessário esclarecer o que o guia apresenta como Conhecimento Explícito e como Funcionamento da Língua. De acordo com a obra, o Conhecimento Explícito da língua pressupõe a existência de um conhecimento implícito. Afirmar a existência do conhecimento implícito implica dizer que ativamos todos os níveis gramaticais de forma inconsciente e eficiente. Ao entendermos isso, conseguimos entender que ensinar gramática não é ensinar algo completamente novo, mas, sim, tornar os nossos alunos conscientes de um conhecimento que eles têm e aplicam, mas do qual não têm consciência.

\footnotetext{
O termo "Conhecimento Explícito" só faz sentido tendo como referência a ideia de que existe conhecimento implícito sobre a língua. Por outras palavras, um trabalho sobre conhecimento explícito assume, de forma inequívoca, que os alunos são falantes competentes, ou seja, utilizadores da língua que mobilizam de forma automática regras gramaticais para gerar e produzir enunciados na sua língua. Consideremos um exemplo simples: o que acontece quando ouvimos uma frase como "Podes fechar a janela?" (COSTA, João et al., 2011, p. 8)
}

Já o Funcionamento da Língua, quando considerado para o ensino, pressupõe que estamos voltados para algo externo a quem aprende, que este não tem qualquer informação sobre aquilo que vai observar e sobre o conhecimento que vai construir, como se a língua fosse algo externo ao ser humano e não uma propriedade biológica. Não estabelece relação entre o conhecimento explícito e a finalidade do "ensino" de gramática. O trabalho em sala de aula está orientado para a correção de erros, atividades voltadas apenas para o uso da língua concernente às práticas sociais.

Podemos ensinar como funciona um microscópio, como funciona uma espécie animal, como funciona a migração das aves e podemos fazê-lo recorrendo a diversas metodologias. Mas, em todos estes casos, pressupomos que estamos a olhar para algo externo a quem aprende, que não tem já qualquer informação sobre aquilo que vai observar e sobre o conhecimento que vai construir. Ora, se acabamos de ver que qualquer falante de uma 
língua, em idade escolar, é um utilizador com conhecimento não consciente de muitas regras gramaticais, é descabido não tirar partido do conhecimento implícito dos alunos para uma explicitação desse mesmo conhecimento. (Guião, 2011, p. 10)

Essa nova abordagem de ensino, baseada no desenvolvimento do Conhecimento Explícito traz consequências para o ensino de língua portuguesa, e língua materna de um modo geral, tais como:

a) investir em descrições mais adequadas da gramática do português;

b) tomar consciência do grau de desenvolvimento linguístico dos nossos alunos e dos aspectos da língua que não decorrem de uma aquisição espontânea;

c) investir num ensino da língua que capitaliza as regularidades e

d) orientar o estudo da gramática em dimensões para além da mera correção do erro.

O Conhecimento Explícito da Língua tomado enquanto competência implica um "saber em uso". Assumir a nuclearidade do Conhecimento Explícito da Língua é revalorizar o seu papel e, consequentemente, conceber um trabalho sobre a gramática que adote abordagens autônomas, com tempo e centradas no desenvolvimento dessa competência. Face ao exposto, uma correta implementação do programa implicará: a) um diagnóstico do conhecimento linguístico dos alunos; b) uma programação (anual) e uma planificação de sequências didáticas em que o trabalho de explicitação da língua é feito com tempo e a partir do conhecimento linguístico dos alunos e c) uma programação que preveja o reinvestimento do conhecimento construído noutras competências.

O trabalho com o desenvolvimento desse tipo de habilidade possui três tipos de objetivos distintos: objetivos instrumentais, atitudinais e cognitivos. Para se conseguir atingir os objetivos instrumentais, é necessário desenvolver sequências de atividades que cumpram pelo menos duas etapas: (i) tomada de consciência e sistematização de propriedades linguísticas e (ii) mobilização dos conhecimentos gramaticais em situações de uso.

Já os objetivos atitudinais consistem em descrever a língua enquanto objeto que existe e que pode ser colocado a serviço do utilizador para melhorar as suas atitudes. Por último, os objetivos cognitivos gerais e específicos consideram o conhecimento gramatical como um objeto de estudo, que constitui um objetivo em si mesmo, ou seja, 
um conhecimento gramatical sólido que deve ser apoiado em descrições rigorosas suportadas por evidências empíricas - e não impressionistas ou infundadas, potenciando a observação de dados e a formulação de hipóteses.

O trabalho com o desenvolvimento desse tipo de conhecimento na educação básica pressupõe métodos que guiam a aprendizagem pela descoberta - construção de conhecimento- e que visam à observação dos dados para a descoberta de padrões regulares. Tal metodologia se constitui em etapas no processo de ensino, que abrangem a:

- Planificação (escolha e preparação dos dados): em que se observa qual o tipo de atividade se pretende propor, sua finalidade geral, se ela segue a abordagem estabelecida, se ela oferece algum desafio de aprendizagem para os alunos e se são dadas instruções claras sobre quais conhecimentos prévios os alunos precisam mobilizar para a realização da atividade.

- Observação e descrição dos dados (formulação de hipóteses e testagem com novos dados): em que são levados em conta os aspectos que dizem respeito à origem dos dados, ao conhecimento implícito do aluno em relação aos dados, à necessidade e suficiência dos dados, à hierarquização da informação contida nos dados (se da mais simples a mais complexo), à probabilidade de dispersão que a informação contida nos dados pode gerar e à possibilidade de os alunos tirarem pequenas conclusões e gerarem hipóteses a partir dos dados.

- Treino: são os momentos de consolidação do conhecimento, no quais a repetição se faz necessária para o automatismo das análises. O guia constata que o problema da repetição não está em sua existência, mas, sim, no momento em que o treino e requisitado, este não deve estar presente antes da consolidação do conhecimento e muito menos fazer-se ausente.

- Avaliação: aplicação do conhecimento construído articulado com competências de leitura, escrita e compreensão e produção, pode ser feita aos poucos ou deixada para o final, quando o conhecimento a ser mobilizado necessita da construção de outros tipos de conhecimentos.

Tais etapas deverão, portanto ser constatadas na hora da elaboração da atividade, sendo necessário pensar qual momento da aprendizagem a atividade pretende 
contemplar; se ela visa à construção de conhecimento; ao treino; à avaliação ou à mobilização de conhecimento gramatical para outras competências.

O guia ainda traz exemplos concretos dos passos que as atividades devem seguir para que proporcionem o desenvolvimento do conhecimento explícito. Observemos um exemplo que trata da identificação das funções sintáticas:

\section{Conjunto 2: Funções Sintáticas}

\section{ACTIVIDADE $1-10^{\circ}$ Ciclo}

1. Tipo de actividade: Construção de conhecimento + treino (3. ${ }^{\circ}$ ano)

2. Descritores de desempenho: Manipular palavras (ou grupos de palavras) em frases, comparar dados e descobrir regularidades (processos de concordância); explicitar regras e procedimentos (distinguir sujeito de predicado)

3. Pré-requisitos: classes de palavras (nome, pronome pessoal e verbo); grupo nominal e verbal; flexão verbal, nominal e pronominal.

4. Questão a que responde: quais são as funções dos grupos mais importantes da frase?

5. Duração estimada: 2 horas

Quais são as funções dos grupos mais importantes da frase?

RECORDA:

$\checkmark$ As palavras nas frases estão combinadas umas com as outras e formam dois grandes grupos - o nominal e o verbal.

$\checkmark$ No grupo nominal, a palavra principal pode ser um nome ou um pronome.

$\checkmark$ No grupo verbal, a palavra principal é um verbo que pode estar acompanhado por outros grupos de palavras.

1. Divide as frases que se seguem em dois grupos, nominal e verbal, colocando-os dentro de caixas, como no exemplo.

a. Os concorrentes cantaram muito bem.

Exemplo: Os concorrentes cantaram muito bem.

b. O António visitou os primos.

c. As crianças construíram uma casa de cartão.

d. Os bebés adormeceram.

e. A Marta aprendeu a tabuada.

2. Repara que, para encontrarmos as duas partes mais importantes da frase, podemos fazer perguntas à frase: 


\section{Os concorrentes cantaram muito bem.}

Pergunta: Quem é que cantou muito bem?

\section{Resposta: Os concorrentes}

Pergunta: O que é que os concorrentes fizeram?

\section{Resposta: cantaram muito bem.}

2.1. Faz este teste com as outras frases para ver se as dividiste correctamente.

2.2. Verifica se podes substituir o grupo nominal das caixas A por um dos seguintes pronomes pessoais: ele, ela, eles, elas.

\section{A}

Os concorrentes
OAntónio
As crianças
Os bebés
4Marta

Pronomes pessoais
Eles
Ele
Elas
Eles
Ela

\section{B}

cantaram muito bem. visitou os primos. construíram uma casa de cartão. adormeceram aprendeu a tabuada.

\section{CONCLUI:}

Ao contrário dos grupos verbais, os grupos nominais podem ser substituídos por pronomes pessoais.

3. Com setas, faz as combinações possíveis entre os grupos nominais e verbais, como no exemplo.

\section{Os concorrentes \\ O António \\ As crianças \\ Os bebés}

A Marta

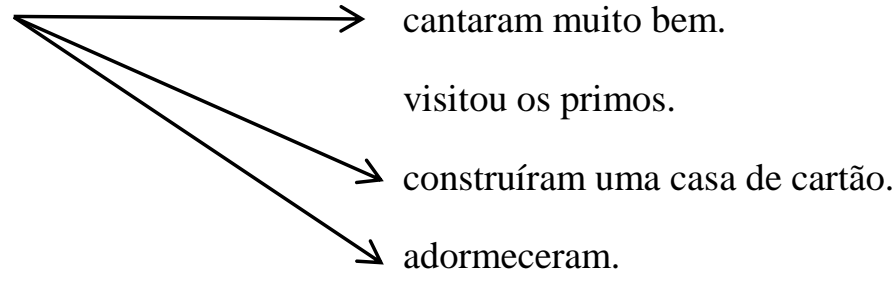

aprendeu a tabuada.

4. Repara que a frase fica incorrecta se disseres $*^{*} \mathrm{O}$ António cantaram muito bem, porque (completa a tabela):

\section{O grupo nominal está $\quad$ O verbo está $\quad O$ verbo devia estar}

na $3^{\mathrm{a}}$ pessoa

no singular na $\quad 3^{\text {a }}$ pessoa

no __ plural na $3^{\mathrm{a}}$ pessoa

no ___singular 
4.2. Preenche o seguinte quadro:

\section{Quando o grupo nominal está}

na $\underline{1^{\mathrm{a}} \text { pessoa no } \underline{\text { singular }}}$

na $2^{\mathrm{a}}$ pessoa no singular

na $3^{\mathrm{a}}$ pessoa no singular

na $1^{\mathrm{a}}$ pessoa no plural

na $2^{\mathrm{a}}$ pessoa no plural

na $3^{\mathrm{a}}$ pessoa no plural

\section{$O$ verbo tem de estar}

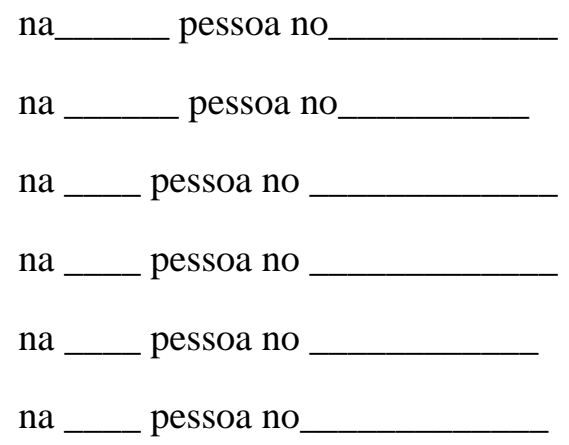

CONCLUI:

Para as frases estarem correctas, o grupo nominal tem de concordar com o em e em

\section{APRENDE:}

$\checkmark$ O grupo nominal que concorda com o verbo em pessoa e número tem a função sintáctica de sujeito.

$\checkmark$ O grupo verbal tem a função sintáctica de predicado.

\section{TREINA:}

5. Combina os grupos das duas colunas e forma frases correctas.

\section{GRUPO NOMINAL - SUJEITO $\mathrm{Tu}$}

A minha casa

$\mathrm{Eu}$

Nós

Os rapazes da minha rua

\section{GRUPO VERBAL - PREDICADO}

passámos as férias na praia.

jogam à bola.

está pintada de verde.

gosto do Natal.

ofereceste-me um caderno novo.

Repara que, no exercício anterior, alguns sujeitos têm apenas uma palavra (tu, eu, nós) e outros têm várias (a minha casa, os rapazes da minha rua).

\section{APRENDE:}

Quando o sujeito tem muitas palavras e não sabes se todas elas desempenham esta função sintáctica, experimenta substituí-las pelos pronomes pessoais ele, ela, eles, elas. 
Exemplo: $\mathrm{Na}$ frase Os rapazes da sala 3 da escola $\mathrm{n}^{\circ} 2$ estão doentes, todas as palavras sublinhadas pertencem ao sujeito porque podem ser substituídas pelo pronome eles - Eles estão doentes.

6. Identifica o sujeito e o predicado nas frases seguintes:

\section{Sujeito}

A Maria comeu um bolo de chocolate.

Os meninos da escola $\mathrm{n}^{\circ}$ 3 fizeram um passeio na serra.

A minha mala verde está guardada no roupeiro.

A professora leva livros ilustrados para as aulas.

As regras da gramática são fáceis de entender.

「u escreveste uma redacção sobre a família.

J carteiro entregou uma encomenda.

O gato do António chama-se Jeremias.
A Maria comeu um bolo de

Os meninos da escola $n^{\circ}$ 3

A minha mala verde

A professora

As regras da gramática

$\mathrm{Tu}$

O carteiro

O gato do António chocolate.

\section{Predicado}

fizeram um passeio na serra.

está guardada no roupeiro. leva livros ilustrados para as aulas. são fáceis de entender.

\section{escreveste uma} redacção sobre a família. entregou uma encomenda. chama-se Jeremias.

Aprendi que:

$\checkmark$ O grupo nominal que concorda com o verbo tem a função sintáctica de sujeito.

$\checkmark$ O grupo verbal tem a função sintáctica de predicado.

$\checkmark \quad$ O sujeito pode ser substituído pelos pronomes pessoais ele, ela, eles, elas.

A atividade apresentada como exemplo do que o guia oferece aos professores encontra-se nas páginas 74 a 78, ela é uma dentre tantos outros exemplos de como a gramática pode ser abordada em sala de aula pela perspectiva da descoberta.

Como se vê claramente planificação da atividade: o assunto a ser abordado, o desempenho que se espera do aluno na realização dessa, o conhecimento prévio necessário para a realização do exercício, o desafio de aprendizagem e a duração da atividade. Informações básicas para que o professor saiba lidar com o material em classe.

A atividade parte da mobilização dos conhecimentos já internalizados pelos alunos e, como se pode observar, o primeiro exercício trabalha com a intuição do aluno sobre a língua, sem oferecer as respostas diretamente, como um gabarito, não deixa de fornecer uma ferramenta para que a correta resolução do exercício seja checada. 
São oferecidos diferentes dados aos alunos, para que eles os examinem e manipulem dento das estruturas linguísticas. Na atividade, os alunos têm de lidar com o uso de pronomes, relações semânticas e relações sintáticas, principalmente no que se refere à concordância. Cada etapa de resolução da atividade estimula os alunos a elaborar conclusões sobre o que foi aprendido a partir das hipóteses que os dados permitem que sejam formuladas. Ainda são fornecidos boxes com a finalidade de cada etapa da aprendizagem, que tipo de conhecimento cada etapa da atividade visa gerar. São apresentadas de maneira clara as etapas da atividade como um todo, desde a construção de conhecimento até o treino.

\subsubsection{Considerações sobre a leitura Costa et al. (2011)}

O guia tem a função de orientar a prática docente, em Portugal, com relação ao componente curricular Língua Portuguesa. Nele são apontadas diretrizes para o "ensino" a partir de uma abordagem ativa da descoberta com o objetivo de desenvolver o Conhecimento Explícito da Língua. Vê que os pressupostos gerativistas aparecem de maneira mais clara no guia, que já pressupõe a língua como um conhecimento internalizado que deve ser trazido à consciência, assim como os estudos de Lobato (2003), Pilati; Naves; Vicente \& Salles (2011), Vicente \& Pilati (2012) e Silva (2013), além de considerar o conhecimento prévio e a competência nos processos de aprendizagem da gramática padrão.

As questões metodológicas já aparecem no guia de maneira mais sistematizada, se o analisarmos sob o arranjo hierárquico proposto por Richards \& Rodgers (2003) observamos que, no que diz respeito à abordagem, método e técnica, o guia apresenta:

- Abordagem: está sistematizada a partir do momento em que se elege o Conhecimento Explícito como objeto de trabalho.

- Método: consiste na tomada de consciência e sistematização de propriedades linguísticas e mobilização dos conhecimentos gramaticais em situações de uso. Além de apresentar o objetivo do método: "capitalizar regularidades".

- Técnica: se baseia na observação do fenômeno, manipulação dos enunciados e formulação de hipóteses, verificação das hipóteses, formulação e regras e estabelecimento de procedimentos, aplicação das descobertas a contextos diversificados (prática) e avaliação/reinvestimento dos conhecimentos. 
Quanto ao que é proposto pelo livro Como as pessoas aprendem: cérebro, mente e escola (2010), o trabalho com o Conhecimento Explícito se apresenta, na teoria, compatível com o conceito de Conhecimento Utilizável, além de apresentar um conceito mais eficaz de conhecimento prévio para o ensino, isto é, correspondente com o que os estudos gerativistas consideram como conhecimento prévio. O trabalho com a abordagem do Conhecimento Explícito ainda prioriza a metacognição no processo de tornar explícito o conhecimento até então inconsciente e o reconhecimento de padrões, quando aponta que a metodologia visa à capitalização de regularidades da língua. No entanto, tal consonância teórica não se verifica por completo na prática, uma vez que as atividades sugeridas não apresentam exercícios destinados à utilização do conhecimento.

Como aponta o trabalho de Xavier (2012), o a metodologia pela descoberta, que trabalha com o Conhecimento Explícito da Língua, tem um objetivo triplo: a) desenvolver a consciência linguística nos alunos; b) sistematização e explicitação das regularidades da língua e c) mobilização dos conhecimentos adquiridos na produção e compreensão de textos. Prioriza-se a manipulação da língua no sentido laboratorial, refletindo e tirando conclusões.

\footnotetext{
São, assim, objetivos principais da abordagem ativa de descoberta fazer compreender as grandes regularidades do funcionamento da língua; remeter para as capacidades de observação, experimentação, raciocínio dedutivo, indutivo e argumentação e contribuir para a construção progressiva dos conhecimentos gramaticais. (Xavier, 2012, p.470 - 471)
}

A autora, baseada nos estudos de Chartrand (1996), sugere o que seriam as seis etapas dessa abordagem:

$1^{\mathrm{a}}$ - observação do fenômeno: os alunos agrupam enunciados retirados de um contexto conhecido, classificam, observam, apresentam conclusões e determinam quais questões serão exploradas.

$2^{\mathrm{a}}$ - manipulação dos enunciados e formulação de hipóteses: os alunos examinam como um enunciado reage quando manipulado em termos de sua estrutura e formulam hipóteses a partir dos resultados obtidos.

$3^{\mathrm{a}}$ - verificação das hipóteses: as hipóteses são testadas com outros dados para serem validadas, ou não, e então tornarem-se regras. 
$4^{\mathrm{a}}$ - formulação e regras e estabelecimento de procedimentos: os alunos formulam as regras com suas próprias palavras e checam o que criaram com o que as gramáticas indicam.

$5^{\text {a }}$ - prática: aplicar as descobertas a contextos diversificados gerando "automatismos" quanto à resolução de situações-problema.

$6^{\mathrm{a}}$ - avaliação/reinvestimento dos conhecimentos: transferência dos novos conhecimentos nas atividades de leitura, escrita e oralidade.

Para que a abordagem tenha sucesso, Xavier (2012) aponta a necessária relação entre os fenômenos estudados e a produção textual, sempre se atendo aos erros dos alunos, pois são esses que demonstram os conhecimentos que não foram desenvolvidos.

A autora faz a ressalva de que não se pode dizer que a abordagem tem o sucesso garantido, e nem que seja o método garantido para todas as situações de estudo gramatical, além de exigir certo nível de preparação linguística e de tempo na organização das atividades. No entanto, a abordagem ativa da descoberta já demonstrou resultados, como: aumento da curiosidade por parte dos alunos, desenvolvimento da autonomia e pensamento científico desses.

\subsection{Considerações sobre o capítulo}

O presente capítulo teve o objetivo de apresentar estudos sobre como a aprendizagem ocorre e sobre abordagens de ensino, além de analisar duas propostas de métodos de ensino de língua portuguesa. Para tanto, foi abordada a obra Como as pessoas aprendem: cérebro, mente e escola (2010), conjunto de estudos destinados a compreender os processos de aprendizagem, os estudos de Richards \& Rodgers (2001) e Fink (2003), estudos que tratam da organização de metodologias de ensino e, por fim, os PCN's (1997) e o Guião (2011), documentos específicos que direcionam o ensino de língua materna no Brasil e em Portugal respectivamente.

Ao longo das análises realizadas neste capítulo, observou-se a importância que as descobertas acerca da construção do conhecimento tiveram para a reelaboração das práticas pedagógicas aplicadas ao ensino de línguas. O conhecimento prévio estabeleceu-se como o principal ponto de partida para a aprendizagem de novos conteúdos e, com isso, o ponto de partida, também, das metodologias que visam à aprendizagem pela descoberta. 
O conhecimento deve deixar de ser considerado apenas como o armazenamento de informações e passa a se estabelecer como Conhecimento Utilizável, isto, é aquele que é recuperado para ser aplicado às situações-problemas que o exige. Com isso deve passar a ser fundamental nas metodologias de "ensino" o desenvolvimento da metacognição nos alunos, pois é com essa habilidade que eles são capazes de monitorar a própria aprendizagem.

Constatou-se com o livro Como as pessoas aprendem: cérebro, mente e escola (2010) e confirmou-se com o Guião de Implementação do Programa de Português do Ensino Básico (2011) que o "ensino", atualmente, segue a tendência ao reconhecimento de padrões, desenvolvimento da metacognição e capacidade de mobilização dos conhecimentos para outros contextos de aplicabilidade, isto é, a capacidade de transferência, desenvolvendo, assim, o pensamento crítico, criativo e prático.

Viu-se, também, que as práticas pedagógicas, além de observarem tais aspectos, devem ser elaboradas de maneira sistematizada com vistas a seguir um arranjo hierárquico, que não se resume ao mero planejamento de aula, mas que combina abordagem, metodologia e técnica dentro de um design instrucional que norteia os objetivos que se pretende alcançar com a combinação de métodos.

Com relação às diretrizes do ensino de Língua Portuguesa adotadas no Brasil e em Portugal, observou-se que o documento de orientação para o "ensino" de língua portuguesa implementado em Portugal se mostra muito mais bem sistematizado, organizado e prático, do que o implementado no Brasil. Na realidade, não se tem no país um guia oficial para as práticas docentes, apenas diretrizes a serem tomadas no "ensino" de língua, mas que não se comprometem com nenhuma abordagem específica sobre concepção e linguagem e não indica nenhuma metodologia a ser aplicada em sala de aula. Falta-nos um documento que operacionalize as diretrizes apontadas pelos PCN's, lacuna essa que o Guião preenche no que se refere ao "ensino" em Portugal. No Brasil, as discussões sobre as abordagens metodológicas permeiam os discursos, mas ainda não tomaram forma para que se tornem soluções práticas.

Em estudo semelhante ao realizado nesse capítulo, Pilati (2014) apresenta três princípios a serem seguidos para a aprendizagem ocorra de maneira efetiva em sala de aula. Os três princípios são os seguintes: primeiro princípio: levar em consideração o conhecimento prévio do aluno, segundo princípio: promover aprendizagem ativa e terceiro princípio: fazer com que o aluno compreenda os processos envolvidos, dentro do assunto estudado. 
Em relação ao primeiro princípio, a autora afirma que os professores devem prestar atenção aos entendimentos incompletos, às crenças falsas e às interpretações ingênuas dos conceitos que os aprendizes trazem consigo sobre determinados assuntos. Considerando esse primeiro princípio, é importante mostrar aos alunos o funcionamento da língua humana sob diferentes perspectivas para que o aluno possa compreender o próprio objeto de estudo e os objetivos das aulas de português.

Em relação ao segundo princípio, a autora defende que para que haja o aprendizado com o entendimento, é importante que as pessoas aprendam a identificar quando aprendem algo e quando precisam de mais alguma informação. Esse aprendizado ativo requer que, nas práticas de sala de aula, haja momentos para a criação do sentido, para a auto avaliação e para a reflexão sobre o que funciona e o que precisa ser melhorado dentro do processo de aprendizagem. Essas práticas aumentam o grau em que os alunos transferem sua aprendizagem para novos cenários e eventos. Em relação ao ensino de gramática, é importante que as aulas sejam planejadas para que os alunos tenham contato com a língua em uso e para que possam usá-la efetivamente, para que os alunos possam compreender o que são as diferentes estruturas linguísticas e em que contextos podem usá-las. Em outras palavras, os alunos devem experimentar nas aulas de gramáticas as diferentes formas de expressão da modalidade escrita da língua (os diferentes gêneros), não apenas como expectadores, mas, sim, como protagonistas do processo de produção textual, para que possam testar seus conhecimentos, analisar formas gramaticais, reconhecer novas formas linguísticas e desenvolver suas habilidades. Somente de forma ativa, poderão ter consciência dos conhecimentos que já possuem sobre formas linguísticas típicas da escrita ou sobre variedades linguísticas. Além disso, poderão, por meio da prática e da reflexão, compreender em quais aspectos estão tendo dificuldade, como melhorar tais aspectos etc.

Em relação ao terceiro e último princípio, que é o de proporcionar aos alunos o conhecimento dos processos envolvidos, Pilati (2014) afirma que para desenvolver uma competência numa área de investigação, os estudantes precisam: a) possuir uma base sólida de conhecimento factual, b) entender os fatos e as ideias no contexto do arcabouço conceitual e c) organizar o conhecimento a fim de facilitar a recuperação e a aplicação.

O professor deve levar seus alunos a: a) aprender a identificar padrões; b) desenvolver compreensão profunda do assunto; c) aprender a quando, como e onde usar o conhecimento - conhecimento circunstanciado; d) possuir acesso fluente ao 
conhecimento. e) ter conhecimento do conteúdo pedagógico e f) aprender com metacognição e para toda a vida.

Entre as atividades que são sugeridas pela autora para que se possa promover um entendimento sobre o funcionamento da língua e promover a aprendizagem ativa sobre como a língua humana funciona, citam-se as seguintes atividades:

1) Oficina sobre a estrutura linguística com material reciclado;

2) Atividades de revisão textual e de reescrita;

3) Análise de aspectos gramaticais em poemas e trechos literários.

\section{Capítulo 3. Aplicação da metodologia e análise de resultados}

Este capítulo tem três objetivos: o primeiro é o de apresentar os conceitos de sujeito e predicado que foram usados na elaboração da atividade (conforme Duarte 2007 e Raposo 2014); o segundo objetivo é apresentar e explicar as concepções teóricas subjacentes à atividade elaborada, segundo os pressupostos teóricos vistos no capítulo 2; por fim será apresentada a metodologia da aplicação da atividade e os resultados da aplicação da atividade em sala de aula com turma do $7^{\circ}$ ano do Ensino Fundamental.

\subsection{Pressupostos teóricos sobre a noção de sujeito de predicado}

Essa subseção visa cumprir o primeiro objetivo deste capítulo, isto é, serão apresentados os conceitos de sujeito e predicado que foram utilizados na elaboração da atividade aplicada aos alunos do $7^{\circ}$ ano do ensino fundamental. Tais conceitos foram retirados das leituras de Duarte (2007) e Raposo (2014), que estarão aqui apresentadas em ordem cronológica.

\subsubsection{A reflexão crítica de Duarte (2007) sobre os termos da oração}

Duarte (2007), após fazer uma revisão sobre os conceitos sintáticos usados nas gramáticas tradicionais, baseada na proposta de Mira Mateus et all (2003), apresenta 
uma crítica à classificação dos termos da oração como "essenciais", "integrantes" e “acessórios". Segundo a autora, tal divisão leva o aluno a induzir que há distinções em relação à importância dos termos na oração, ao invés de contribuir para que os alunos tenham uma visão das relações entre os constituintes da oração. De acordo com a autora,

\footnotetext{
À imprecisão resultante do uso de tais adjetivos alia-se a falta de complementariedade entre os termos que compõem cada um dos três grupos: o "predicado", por exemplo, é um termo "essencial", enquanto os complementos verbais, que fazem parte o predicado, são termos "integrantes". Finalmente, os grupos apresentam elementos que se situam em diferentes níveis da hierarquia sintática: os complementos verbais e nominais, de um lado, e os adjuntos adverbiais e adnominais, de outro, classificados entre os termos "integrantes" e "acessórios", respectivamente, reúnem "termos" ligados ao verbo e ao nome. (Duarte, 2007, p. 185)
}

Outra crítica à gramatica tradicional feita pela autora, com base em Perini (1985), é sobre a mistura que a gramática tradicional faz com critérios semânticos e sintáticos. As gramáticas tradicionais usam critérios semânticos para definir sujeitos e predicados como "o ser sobre o qual se faz uma declaração", que o predicado é "tudo aquilo que se diz do sujeito", mas usa critérios sintáticos ao propor que sujeito e predicado correspondem à estrutura de tópico e comentário. A autora observa ainda que outro problema para esse tipo de classificação é que as definições dos termos acabam dependendo umas das outras, sendo o conceito de sujeito estabelecido a partir da definição do predicado e vice versa.

A proposta de Duarte é que a estrutura da oração seja analisada em sala de aula com base num ponto de vista "estrutural". Para a autora, deve-se iniciar a análise a partir do elemento nuclear que dá origem à oração, o "predicador", porque é esse elemento que projeta os constituintes centrais da oração, ou seja, é o responsável pela estrutura principal da oração. Duarte (2007) busca entender a seleção semântica que o predicador faz, como se observa nos exemplos (1), (2), (3) e (4) (p. 187):

Os predicadores podem projetar as seguintes estruturas:

(1) estruturas com 3 argumentos: a. Ele deu o dinheiro aos pobres.

b. Eu dividi o pão com os pobres.

c. Eu levei as crianças ao colégio. 
(2) estruturas com 2 argumentos: a. Ele matou o pássaro.

b. Ele telefonou para o pai.

c. Eles acreditaram em você.

d. Eles moram no Rio.

(3) estruturas com 1 argumento: a. As crianças pulam.

b. Chegou uma encomenda.

c. _ Houve muitas festas.

(4) estruturas sem argumento: _ Choveu.

Em relação à função sintática sujeito, a autora utiliza o termo argumento externo. Para Duarte, a distinção feita nas gramáticas tradicionais e livros didáticos sobre a quantidade de núcleos do sujeito, se simples ou composto é desnecessária. A autora considera essa classificação um aspecto "absolutamente irrelevante", pois o ponto crucial para a análise dos argumentos externos é a presença ou não do sujeito e a referência dos termos. A autora propõe, portanto, que o sujeito seja classificado quanto à forma - expresso ou não expresso - e quanto à referência - definida, indefinida ou não ter qualquer referência.

Em relação à forma de apresentar tais temas aos alunos, autora defende que, num primeiro recorte, trabalhe-se com o(s) predicador(es), seus argumentos e os eventuais adjuntos adverbiais. Já quanto aos demais elementos da oração, com funções sintáticas diferentes da de sujeito e predicado (os adjuntos adnominais, o aposto e o complemento nominal, o complemento nominal), a autora não apresenta uma proposta concreta para a abordagem de tais temas em sala de aula.

Sobre as implicações da organização dos termos na oração, Duarte (2007) aponta que a análise deve levar em conta, além da estrutura projetada pelos predicadores, o momento em que as palavras se organizam em sintagmas e estes, em orações, estabelecem-se relações de concordância, de regência e de ordem.

De acordo com Duarte (2007), a análise gramatical realizada em sala de aula não deve se limitar a mera classificação dos termos. Reconhecer e identificar os constituintes da sentença é importante para que o aluno entenda, por exemplo, relações de concordância, como também para a boa utilização dos sinais de pontuação. Enfim, para a autora, cabe ao professor levar o aluno a produzir sentenças a partir de 
predicadores verbais e nominais e torná-lo capaz de identificar os padrões sentenciais de sua língua (e funcionamento), que todo falante domina sem esforço e que o estudante tem a chance de conhecer e analisar.

\title{
3.1.2. A abordagem de Raposo (2014) para os conceitos de sujeito e predicado
}

Em Raposo (2014), as "frases" são analisadas sob duas perspectivas: a da organização funcional e a da organização estrutural.

\begin{abstract}
$\mathrm{Na}$ análise que desenvolvemos nesta secção, os constituintes classificam-se segundo a função que desempenham na articulação lógico-semântica da frase, em termos, por um lado, da noção de predicação, e, por outro, da concepção das frases como sendo representações de situações em que participam diversas entidades em circunstâncias particulares. As noções relevantes, nestas perspectivas, são as de sujeito, predicado, predicador, argumento, complemento e adjunto adverbial. Assim para dar desde já um exemplo, a frase o juiz interrogou as testemunhas pode ser representada em termos da sua organização estrutural (cf. (23a)) e em termo de sua organização funcional (cf. (23b)): (Raposo, 2014, p. 351)
\end{abstract}

(23) a. [sN O juiz] [sv interrogou [SN as testemunhas]].

b. [sujeito $\mathrm{O}$ juiz] [predicado interrogou [complemento direto as testemunhas]].

De acordo com o autor, reconhecer a complementariedade desses dois tipos de análise é umas das contribuições mais importantes das teorias linguísticas recentes, pois tal complementariedade acaba por reconhecer a existência de relações sistemáticas entre a classe sintagmática dos constituintes e a sua função.

Em relação aos conceitos de sujeito e predicado, afirma-se que esses representariam a divisão funcional mais abrangente das frases e que em tais noções assentam no conceito lógico-semântico de predicação, que é um conceito central na organização funcional das frases de acordo com o autor.

Raposo (2014) define a predicação como "um modo particular de organizar linguisticamente a informação expressa por uma proposição" (p. 352). Seria a descrição de uma situação por meio da articulação de dois elementos: uma entidade sobre a qual se diz algo e um comentário sobre essa entidade, sendo esses: o sujeito da predicação, sintagma nominal, e o predicado, sintagma verbal, respectivamente. Como aparecem nos exemplos da página 352, (24) a, b e c, nos quais o sujeito aparece em itálico e o predicado aparece sublinhado: 
(24) a. A Joana é inteligente.

b. A Joana preparou uma sandes para o filho.

c. A Joana foi condenada a três anos de prisão.

Com isso, o autor faz a ressalva de que:

\begin{abstract}
No modelo gramatical aqui adotado, as noções de "sujeito" e "predicado" são concebidas como funções gramaticais exercidas por constituintes pertencentes a determinadas classes gramaticais, Assim, p.e., em (24a), a Joana é um sintagma nominal que exerce nessa frase a função de sujeito, e é inteligente é um sintagma verbal com a função de predicado. Para simplificar a exposição, no entanto, referimo-nos frequentemente a esses constituintes pelos termos "sujeito", "predicado", etc., em vez de os referirmos pelas expressões mais longas "SN com a função de sujeito", "SV com a função de predicado", etc. (Raposo, 2014, p.353)
\end{abstract}

Reconhece-se na obra que, em português, o sujeito normalmente precede o predicado, mas que a ordem desses dois elementos pode ser alterada quando associada a fenômenos semânticos como a topicalização e a focalização.

Raposo faz uma distinção entre três conceitos relevante para a análise sintática: sujeito da predicação, sujeito gramatical, tópico e comentário. Para autor, tais conceitos são distintos. A fim de ilustrar a diferença entre tópico e sujeito da predicação o autor utiliza os seguintes exemplos:

(25) a. Esse livro, as minhas amigas compraram para Maria.

b. A viagem ao México, nós a concretizamos nas férias passadas.

Nas frases mais canônicas, a que serviram de base para a tradição gramatical ocidental, o sujeito da predicação tem sido conceituado duas formas: i) como o sintagma nominal que concorda em número e pessoa com o verbo e ii) como o elemento sobre o qual se faz algum comentário. No entanto, nos exemplos acima, observamos que o SN que concorda com as formas verbais compraram e concretizamos, nas orações a que pertencem, não é o mesmo SN sobre o qual se faz um comentário. Em (25a), o SN minhas amigas concorda com a forma verbal compraram, sendo, no entanto, sobre o SN esse livro que se faz um comentário. Semelhante estrutura ocorre em (25b), o SN 
nós concorda com a forma verbal concretizamos, mas é sobre o SN A viagem ao México que se faz um comentário.

Com base nessa observação, Raposo diferencia sujeito da predicação (sujeito semântico), que seria o SN que introduz a entidade sobre a qual se diz algo, de sujeito gramatical, SN que concorda em pessoa e número com o verbo.

Os exemplos apresentados em (25) correspondem ao que a teoria linguística designa como tópico e comentário, que seriam o sintagma inicial da oração e aquilo que exprime o que se diz sobre o tópico respectivamente. Os SN esse livro e a viagem ao México são o sujeito da predicação mais abrangente veiculada pelas orações, mas não são o sujeito gramatical.

Tendo em vista as considerações acerca da concepção de sujeito na organização funcional das frases feitas por Raposo (2014), essa pesquisa se utilizou da noção de sujeito gramatical nos critérios de identificação do sujeito para a elaboração da atividade.

Com relação às predicações, o autor considera a que elas possam ser de base verbal, de base adjetival e de base nominal, como nos exemplos (26a), (27a) e (28a):

(26) a. O gato comeu o rato.

(27) a. O Pedro é inteligente.

(28) a. O Zé é professor de matemática.

Conforme Raposo (2014) em uma predicação, "o predicado contém sempre um item central, que representa o tipo de situação na qual o sujeito se encontra envolvido, ou numa propriedade que lhe atribui" (p. 357). Assim, em (26a) representa-se a situação de comer, em (27a) atribui-se a Pedro a característica de ser inteligente e em (28a) falase que Zé é professor. E seriam essas três palavras os itens centrais aos quais o autor se refere como formadores da base da predicação, ou seja, os predicadores.

De acordo com Raposo (2014), os predicadores são aqueles elementos que exprimem propriedades das entidades representadas pelos argumentos com os quais se combinam. São eles que definem o conteúdo fundamental das proposições e selecionam os argumentos para lhe completarem o sentido, constituindo não só o núcleo semântico da frase com também o núcleo semântico do predicado. Podem funcionar como predicadores os verbos, adjetivos, nomes, determinadas preposições e alguns advérbios. Tendo em vista que todas as orações requerem um verbo, quando o predicador não é o 
verbo, mas, sim, qualquer uma das outras classes gramaticais destacadas, o sintagma verbal contém um tipo particular de verbo, o verbo copulativo, que não podem funcionar como predicadores por não terem um conteúdo descritivo.

Os argumentos representam as entidades que participam das situações descritas nas orações. São eles selecionados pelo predicador para que a oração seja formada e podem ser sintagmas nominais, sintagmas preposicionais, orações finitas ou orações infinitivas.

O predicador seleciona um determinado número de argumentos conforme suas propriedades semânticas e esse número de argumentos pode variar de 0 a 3 , como já visto em Duarte (2007). No entanto o autor também mostra um pequeno número de verbos que podem selecionar 4 argumentos. São verbos que denotam movimento ou transações como nos exemplos (34 a, b, c, d, e e):

(34) a. O João levou [o carro] [do stand de vendas] [para sua casa].

b. $\underline{\text { O Pedrinho trouxe [a bola] [do jardim] [para a aula] }}$.

c. A Isabel comprou [um livro] [ao Luís] [por vinte escudos].

d. A Felisbela pagou [vinte euros] [ao comerciante] [por um par de sapatos].

e. A Carla trocou [um par de sapatos] [por uma camisola] [com Maria].

De acordo com o autor, os argumentos dos verbos de movimento correspondem ao agente da ação, à entidade afetada pela ação, à origem do movimento e ao seu destino. Já os argumentos dos verbos de transação correspondem aos indivíduos que participam da transação e às entidades que são transacionadas.

\subsection{Descrição da atividade proposta}

A atividade a ser apresentada a seguir foi elaborada com o objetivo de desenvolver o conhecimento linguístico dos alunos sobre as noções gramaticais de sujeito e de predicação no período simples. A estrutura da atividade seguiu modelo apresentado no Guião de Implementação dos Programas de Português do Ensino Básico: Conhecimento Explícito de Língua (2011), conforme apresentado no capítulo 2, com algumas adaptações.

A atividade foi elaborada utilizando os conceitos de sujeito e formação da estrutura apresentados nas seções anteriores. Isto é concebeu-se que a oração é formada 
a partir de uma operação sintática de predicação e que o sujeito é um dos argumentos selecionados pelo verbo (predicador verbal).

A seguir iniciaremos a apresentação da atividade aplicada em sala de aula, seção 3.2.1, ao final dessa etapa serão apresentadas as motivações teóricas para o design instrucional proposto, seção 3.2.2.

\subsubsection{Apresentação da atividade}

Seguindo o design instrucional proposto por Richards \& Rodgers (2001), a atividade tem por:

- Abordagem: a concepção de gramática interna, como exposto em Kato (2005), e o conhecimento explícito da língua adotado pelo Guião (2011).

- Método: a aprendizagem ativa e os procedimentos de descoberta e metacognitivos vistos em Lobato (2003), Costa et al (2011), Vicente \& Pilati (2012) e Pilati (2014) .

- Técnica: consiste na exposição e análise dos dados, para que sejam tiradas conclusões com relação às regras aplicadas à formação das estruturas das orações. Os conhecimentos desenvolvidos são então aplicados ao texto, a partir da revisão textual, e os conteúdos são sistematizados na forma de esquema.

No que diz respeito à técnica, a atividade foi elaborada seguindo seis etapas: 1 . Análise intuitiva dos dados, 2. Construção de critérios para as classificações, 3. Construção das regras, 4. Aplicação das regras formuladas a contextos diversificados, 5. Avaliação com base na revisão de textos e 6. Sistematização do conteúdo.

Diferentemente da técnica adotada pelo Guião (2011), nessa atividade os conhecimentos são vinculados à produção textual e não apenas testados com a marcação de tabelas. Buscou-se fazer com que os alunos fossem capazes de desenvolver não apenas o conhecimento gramatical, mas, também, as habilidades de escrita, leitura e revisão textual.

A seguir passaremos à explicação de cada uma das etapas.

\section{Sujeito e Predicado}


Primeira etapa - Que tipo de elemento pode ocupar a função de sujeito ${ }^{2}$ ?

Observe a forma verbal a seguir:

\section{ANUNCIARAM}

1. Quais dos elementos a seguir poderiam ter praticado a ação expressa pela forma verbal em questão? Circule-os.
As cadeiras
Os jornais
O jovem
Os funcionários
A menina

2. Por que os termos "O jovem" e "A menina" não poderiam ter praticado a ação?

3. Por que o termo "Os jornais" poderia ser sujeito da ação expressa pelo verbo, mas o termo "As cadeiras" não o poderia se ambos se tratam de objeto inanimados?

4. Por que os termos "Os jornais" e "Os funcionários" poderiam ser sujeitos de tal verbo? O que eles apresentam que as opções "O jovem" e "A menina" não possuem?

Obs.: Como você observou na questão 4, os termos $O$ jovem e $A$ menina, apesar de poderem praticar a ação expressa pelo verbo não poderiam exercer a função de sujeito, uma vez que o verbo está no plural e os termos em questão se encontram no singular ${ }^{3}$.

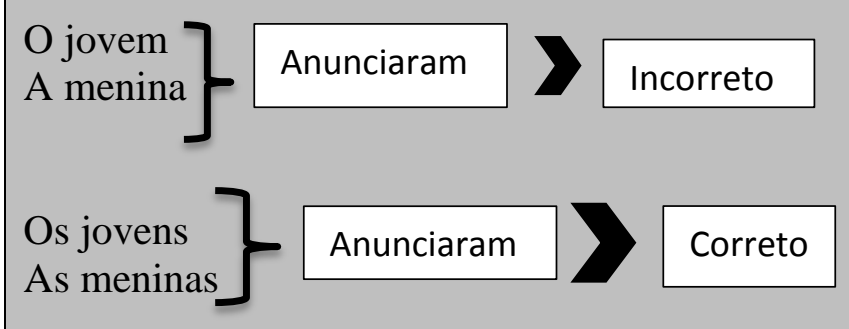

Esse tipo de relação, que se estabelece entre o sujeito e o verbo, na qual ambos devem estar no plural ou ambos devem estar no singular, é o que chamamos de concordância. Ou seja, o sujeito e o verbo devem concordar em número (singular ou plural).

Como você pôde ver, temos dois critérios para relacionar o sujeito ao verbo: um critério semântico e um critério sintático.

- Critério Semântico - diz respeito à possibilidade de que o sujeito pratique

\footnotetext{
${ }^{2}$ Termo utilizado apenas para se referir à função sintática. As noções cem relação à definição de sujeito são trabalhadas ao longo da atividade.

${ }^{3}$ Manteve-se a estrutura da atividade, pois esse foi o modelo aplicado em sala de aula, no entanto observou-se que as noções de "correto" e "incorreto" não são adequadas para o tratamento das relações de concordância entre sujeito e predicado, tendo em vista e existência de concordâncias variáveis. Seria preferível, portanto, trabalhar com as noções de "adequado" e "inadequado".
} 


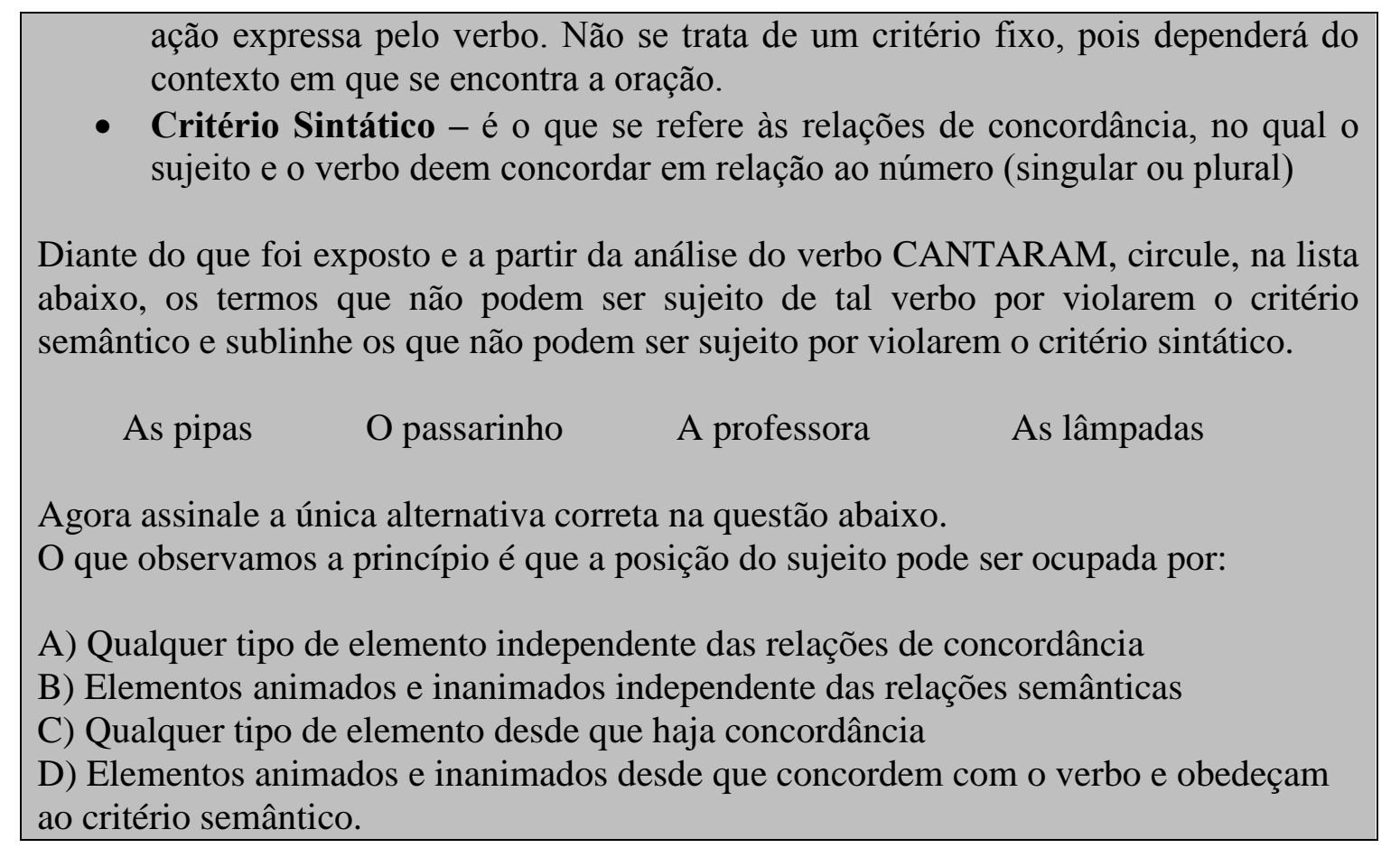

Segunda etapa - Relacionando nomes a verbos.

1. Relacione os elementos da coluna $\mathrm{A}$ às afirmações presentes na coluna $\mathrm{B}$ de maneira coerente.

\section{Coluna A}

Maria

João

A cadeira

As crianças

O bebê

Os livros

As pesquisas

\section{Coluna B}

caíram da mesa

chegou cedo do trabalho

é bonita

quebrou

mostraram novos dados

precisam brincar

chora

2. Algum dos elementos presentes na coluna A poderia ser relacionado a mais de um elemento da coluna B? Caso isso ocorra, indique o elemento e as possíveis combinações. Caso isso não possa ocorrer, justifique.

3. A que elemento você relacionou o termo "A cadeira"? Justifique. 
4. O termo "A cadeira" poderia ser relacionado ao elemento "chegou cedo do trabalho". Por quê?

5. O termo "O bebê" poderia ser relacionado ao elemento "caíram da mesa". Por quê?

6. O que você observou nos elementos da coluna A e B Ao relacioná-los?

Na questão abaixo, assinale a única alternativa correta.

Nessa etapa observamos que sujeito se relaciona ao verbo:

A) Apenas por questões semânticas (de sentido lógico)

B) Por questões semânticas (de sentido lógico) e sintáticas (de concordância)

C) Apenas sintáticas (de concordância)

D) Não há nenhum critério específico para relacionar o sujeito ao verbo

Terceira etapa - Identificando os tipos de sujeito

Observe as orações abaixo e circule os verbos nelas presentes:

a) Maria come muito.

b) Chove forte no sul do país.

c) Os dados revelam o inesperado.

d) Roubaram o meu celular.

e) O cálculo e a resposta são contraditórios.

f) Vi você no ônibus.

1. A cada um dos verbos circulados faça a pergunta "QUEM?" " antes do verbo e escreva abaixo as respostas obtidas.
a)
b)
c)
d)
e)
f)

\footnotetext{
${ }^{4}$ A pergunta "QUEM?" não se mostrou suficiente para tratar de dados do tipo "O cálculo e a resposta". Portanto, faz-se necessário que, na reformulação da atividade, seja acrescentada a pergunta "O QUE?".
} 
2. As respostas obtidas em 1 correspondem àquilo que nós identificamos como "sujeito". Pensando nessa afirmação, responda:

a) Alguma das orações analisadas não apresenta resposta para a pergunta “QUEM?”? Quais são elas e o que elas indicam?

b) Alguma das orações analisadas apresenta uma resposta à pergunta “QUEM?" sem, no entanto, essa resposta estar expressa na oração?

Assinale a única alternativa correta.

Até agora verificamos que:

A) Apenas elementos animados podem responder a pergunta "QUEM?"

B) Quando o elemento que serve de resposta à pergunta “QUEM?" não está expresso na oração, é um sinal de que a oração não tem sujeito

C) Tanto elementos animados, quanto elementos inanimados podem responder a pergunta "QUEM?", sendo que estes podem, ou não, estar expressos na oração.

D) Quando o sujeito não está expresso na oração ele não pode ser identificado.

c) Divida as orações no quadro abaixo de acordo com a possibilidade, ou não, de se circular o sujeito na oração, ou seja, com o fato de eles estarem expressos ou não.

\begin{tabular}{|l|l|}
\hline Sujeitos expressos & Sujeitos não-expressos \\
\hline & \\
\hline & \\
\hline & \\
\hline & \\
\hline & \\
\hline
\end{tabular}

d) Com base no que foi respondido nas questões anteriores, é possível afirmar que não é possível identificar os sujeitos quando estes não estão expressos? Justifique.

e) Agora distribua as orações seguintes no quadro abaixo de acordo com a forma com que o sujeito se apresenta na oração: expresso, não-expresso identificável, não-expresso e não-identificável. 
I. Índices de desempenho alarmam os educadores.

II. O material da escola ficou em cima da mesa.

III. Vou ao shopping à tarde.

IV. Trovejou durante à noite.

V. Celulares e aparelhos eletrônicos permanecem desligados.

VI. Falaram de você na reunião.

VII. A criança come muito.

VIII. Brincamos com os vizinhos.

IX. A caneta e o lápis sumiram.

$\mathrm{X}$. Faz três meses desde a reforma.

XI. O que faltou na festa?

XII. Eles disseram a verdade.

\begin{tabular}{|l|c|c|}
\hline Sujeito expresso & $\begin{array}{c}\text { Sujeito não-expresso } \\
\text { identificável } \\
\text { (Sujeito Desinencial) }\end{array}$ & $\begin{array}{c}\text { Sujeito não-expresso e } \\
\text { não-identificável } \\
\text { (Sujeito Inexistente) }\end{array}$ \\
\hline & & \\
\hline & & \\
\hline & & \\
\hline & & \\
\hline & & \\
\hline & & \\
\hline & & \\
\hline
\end{tabular}

f) No que diz respeito às frases que preenchem a coluna do "sujeito expresso", em quais delas mais de um substantivo responde a pergunta "QUEM?"?

g) Agora divida as orações que responderam ao item $\mathbf{f}$ em duas colunas: as que apresentam apenas um substantivo à pergunta "QUEM?" (que comumente classificamos como sujeito simples) e as que apresentam mais de um substantivo como resposta à pergunta "QUEM?" (classificado como sujeito composto). ${ }^{5}$

\begin{tabular}{|c|c|}
\hline Sujeito Simples & Sujeito Composto \\
\hline & \\
\hline & \\
\hline & \\
\hline
\end{tabular}

Assinalando a única alternativa correta, responda.

Nessa etapa nós verificamos que:

\footnotetext{
${ }^{5}$ As respostas a este item foram descartadas das análises pelo fato de ele apresentar problemas no enunciado.
} 
A) Os sujeitos se distinguem em: animados e inanimados

B) O sujeito se distingue em apenas dois tipos: existente e inexistente

C) Há apenas dois tipos de sujeito: simples e compostos

D) Os sujeitos se distinguem em: existentes e inexistente, sendo que, quando há sujeito na oração, este pode ser: simples, composto ou desinencial

Ao todo, podemos classificar o sujeito em quantos tipos?

Além de substantivos, que outra classe de palavra também pode ocupar a posição de sujeito?

Quarta etapa - relação entre o sujeito e o verbo

1. Observe a frase abaixo:

A garota disse que não vai viajar.

a) Quem é o sujeito da forma verbal em destaque?

Agora observe:

Que não vai viajar, disse a garota.

b) Os elementos da oração ou a relação semântica entre eles foram alterados? O que se alterou de fato no período?

c) Sendo assim, qual é o sujeito do verbo em destaque?

Observe novamente:

Era noite quando os homens chegaram.

d) Qual elemento é o sujeito do verbo em destaque?

e) É possível afirmar que o sujeito das orações é sempre o elemento que as iniciam? Por quê? 
Continue observando:

Que você seja feliz é o que desejo.

f) Que estrutura corresponde ao sujeito do verbo em destaque?

g) O sujeito identificado corresponde a um substantivo ou a uma oração?

h) Pode-se afirmar que o sujeito será sempre uma palavra com valor substantivo? Por quê?

Assinale a única alternativa correta.

Nessa etapa podemos observar que:

A) O sujeito é sempre o primeiro termo da oração;

B) O sujeito nem sempre é o primeiro elemento da oração, além de, também, poder ser expresso por uma oração (sujeito oracional);

C) Apenas substantivos podem ocupar a posição de sujeito;

D) O sujeito só é o primeiro elemento da oração quando está expresso por uma oração (sujeito oracional).

Quinta etapa - Você o revisor.

1. Identifique os sujeitos das formas verbais destacadas no parágrafo abaixo.

"A viagem não acaba nunca. Só os viajantes acabam. E mesmo estes podem prolongar-se em memória, em lembrança, em narrativa. Quando o visitante sentou na areia da praia e disse:

'Não há mais o que ver", saiba que não era assim. O fim de uma viagem é apenas o começo de outra. É preciso ver o que não foi visto, ver outra vez o que se viu já, ver na primavera o que se vira no verão, ver de dia o que se viu de noite, com o sol onde primeiramente a chuva caía, ver a seara verde, o fruto maduro, a pedra que mudou de lugar, a sombra que aqui não estava. É preciso voltar aos passos que foram dados, para repetir e para traçar caminhos novos ao lado deles. É preciso recomeçar a viagem. Sempre."”

Acaba -

Acabam -

Podem -

Sentou -

Disse -

É - 
Caía -

Mudou -

É -

2. Agora identifique os sujeitos dos verbos destacados no parágrafo abaixo e reescrevao corrigindo os problemas referentes à concordância entre o verbo e o sujeito.

"Na ânsia por querer conquistar certas coisas na vida - casa própria, carro, um bom emprego-, as pessoas esquecem de viver e só se dá conta disso quando já têm tudo que precisa menos aquele sonho antigo. Aí elas se acham velhas demais para realizar e morre sem nem tentar, um pouco frustradas pela vida ter passado tão depressa. Uma vida assim está longe de ser ruim, mas acho que todos nasce para ter uma experiência extraordinária aqui, viver do seu jeito e deixar a sua contribuição. Chris Guillebeau é um desses caras que podemos ter inveja da vida que leva, ele já conhecem todos os 193 países do mundo e trabalha como escritor provocando as pessoas a fazerem o mesmo: o que quer que você tenha vontade. $\mathrm{O}$ dele era viajar, qual é o seu?"

Sexta etapa - Sistematizando o que foi aprendido

Preencha as lacunas do esquema abaixo de maneira a relacionar corretamente as informações. 


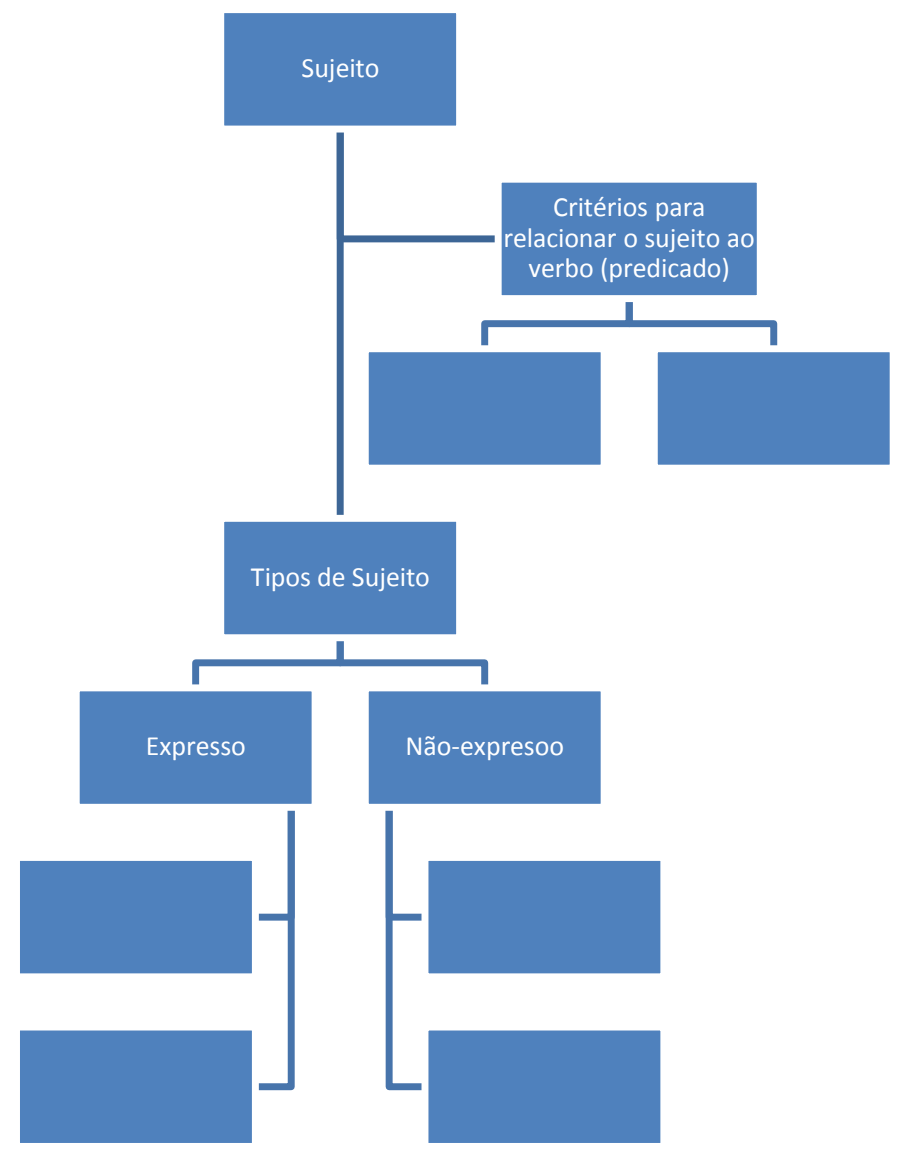

\subsubsection{Comentários sobre a elaboração das etapas}

$1^{\text {a }}$ etapa - Análise intuitiva dos dados: com base nos procedimentos de descobertas presentes em Lobato (2003) espera-se que os alunos, a partir da análise dos dados apresentados, percebam que, a princípio, existem dois critérios básicos para estabelecer uma relação entre o sujeito e o predicado: o critério semântico, e o critério sintático. Para isso, utiliza-se a intuição do aluno com relação à estrutura da língua, e seu conhecimento de mundo para que justifique as possíveis estruturas e o porquê de algumas se apresentarem em desacordo com os conceitos trabalhados.

$2^{\text {a }}$ etapa - Construção de critérios para as classificações: depois de apresentados os critérios, inicia-se nessa etapa as técnicas de eliciação, propostas por Lobato (2003) e aprimoradas por Vicente \& Pilati (2012). Espera-se, nessa etapa, que os alunos consolidem sua aprendizagem com a aplicação do conteúdo a diferentes contextos, sendo explicitado o raciocínio desenvolvido ao estabelecer as relações entre o sujeito e 
o predicado em combinações específicas a fim de que se trabalhe nos aluno o pensamento crítico.

$3^{\text {a }}$ etapa - Construção das regras: Nessa etapa, buscou-se que os alunos desenvolvessem os conhecimentos linguísticos profundos acerca do conteúdo, Como as pessoas aprendem: cérebro mente e ensino (2010) e Pilat et al. (2011). Assim, espera-se que os alunos estabelecem os conceitos para a classificação dos diferentes tipos de sujeito, a partir da identificação das formas verbais; da pergunta "Quem?”; da presença ou não do sujeito na oração, se expressos ou não-expressos; da capacidade de serem identificados, ou não; da classe gramatical que ocupa a função de sujeito e da quantidade de núcleos que o sujeito apresenta. Pretende-se mostrar que apenas um método pode não ser suficiente para que se identifique a que classificação o sujeito pertence, por isso são exigidos, em alguns exercícios, a utilização de mais de um método de identificação, em função do não funcionamento de algum deles, para que o aluno não acabe se acomodando a raciocínio simplista sobre o assunto.

$4^{\mathrm{a}}$ etapa - Aplicação das regras formuladas a contextos diversificados: após apresentar um dado já conhecido e analisado pelos alunos, modifica-se a estrutura das orações para que eles compreendam que o assunto pode aparecer de maneiras diversificadas, espera-se que eles acessem e recuperam as informações de maneira eficiente, como apresentado na obra Como as pessoas aprendem: cérebro mente e ensino (2010) e por Pilati (2014). Para isso, são utilizadas as técnicas de resultado, Lobato (2003), apresentando orações em ordem inversa e sujeitos oracionais, para que o aluno perceba que, mesmo em estruturas, a princípio, desconhecidas, os critérios estabelecidos devem ser levados em consideração e se fazem eficazes na identificação do sujeito.

$5^{\text {a }}$ etapa - Avaliação com base na revisão de textos: é a etapa em que os alunos aplicam o conteúdo, tornando-o Conhecimento Utilizável (cf. Como as pessoas aprendem: cérebro mente e ensino, 2010). A revisão de textos tem o intuito de fazer com que os alunos reconheçam os padrões identificados nas etapas anteriores e saibam mobilizar o conhecimento para a resolução da situação-problema proposta, no caso, a correção do texto. Nessa proposta, trabalham-se paralelamente as habilidades de leitura, compreensão e produção de textos escritos.

$6^{\mathrm{a}}$ etapa - Sistematização do conteúdo: consiste no preenchimento do diagrama com os critérios utilizados na identificação do sujeito das orações e as classificações tradicionais atribuídas a eles. É a etapa em que os alunos organizam o esquema de 
maneira a visualizar e sistematizar os conceitos apreendidos, uma forma de fazer uma revisão do conteúdo estudado.

\subsection{Metodologia utilizada para a aplicação da atividade}

Para testar a eficácia do material didático elaborado, aplicou-se a atividade em uma turma de alunos do $7^{\circ}$ ano do ensino fundamental II de uma escola particular localizada em Sobradinho, Distrito Federal. Foi escolhido o $7^{\circ}$ ano por se tratar da série em que são introduzidas aos alunos as noções dos constituintes da oração, ou seja, é nessa série que se espera que os alunos aprendam a identificar e classificar o "sujeito" e o "predicado".

Foram selecionadas duas turmas para participarem do teste, somando um total de 60 alunos participantes, sendo que uma turma de 30 alunos trabalhou o conteúdo com a atividade elaborada neste trabalho (turma 1) e com a outra turma, também de 30 alunos, foram trabalhados os exercícios que constam no livro didático adotado pela escola (turma 2). Ao final, a turma que utilizou o livro didático respondeu as etapas 5 e 6 da atividade elaborada, etapas destinadas à avaliação e sistematização do conteúdo desenvolvido. Os alunos da Turma 1 já haviam tido duas aulas sobre o conteúdo abordado no exercício, no entanto ainda não haviam realizado nenhuma atividade a respeito.

Tanto a atividade quanto o teste (etapas 5 e 6 apenas) foram aplicados no horário da aula de português pela professora responsável pela matéria. Não foi permitido o acompanhamento da aplicação da atividade, no entanto a professora relatou que não houve maiores problemas na aplicação, mas que foi necessário esclarecer a que correspondem as classificações de sujeito "expresso" e "não-expresso" e que alguns alunos apresentaram dificuldade em responder à etapa três da atividade por não compreenderem completamente o comando das questões. Ao todo a atividade teve a duração de $1 \mathrm{~h}$ e $10 \mathrm{~min}$ e o teste durou cerca de $25 \mathrm{~min}$.

$\mathrm{Na}$ análise dos resultados, foi observada a maneira como os alunos responderam ao material didático elaborado como um todo a fim de identificar possíveis problemas com relação à compreensão dos comandos e análises realizadas pelos alunos. Já as respostas obtidas pelos alunos das turmas 1 e 2 nas etapas 5 e 6 foram observadas em 
contraste a fim de avaliar o desempenho dos estudantes na recuperação e aplicação dos conteúdos trabalhados.

\section{4. Análises dos resultados}

Nesta seção, os dados serão analisados sob dois aspectos: i). O desempenho dos alunos ao longo da execução da atividade, ou seja, de que maneira a compreensão dos enunciados e as respostas obtidas nas questões influenciaram o desempenho dos alunos na aprendizagem do conteúdo abordado. E ii). Os contrastes obtidos nas respostas dos alunos das Turmas 1 e 2 nas etapas 5 e 6 da atividade, isto é, as habilidades que a atividade testada e o livro didático foram capazes de desenvolver nos alunos e os pontos a serem melhorados na formulação dos exercícios.

\subsubsection{Desempenho dos alunos na resolução dos exercícios}

Nesta subseção, serão apresentados os valores numéricos com relação às respostas obtidas em cada uma das etapas realizadas pelos alunos, assim como considerações a respeito do desempenho destes em cada uma das etapas.

- $\quad \mathbf{1}^{\mathbf{a}}$ etapa - Análise intuitiva dos dados:

12 alunos responderam de maneira correta todas as questões presentes na etapa;

5 alunos apresentaram problemas na compreensão dos enunciados;

6 alunos não responderam ao box em que constam as conclusões acerca do conteúdo desenvolvido na etapa;

9 alunos consideraram o critério sintático para a identificação do sujeito, mas não o semântico;

2 alunos apresentaram respostas incoerentes;

1 aluno não reconheceu nenhum dos critérios apresentados para a identificação do sujeito.

Os resultados recolhidos nessa etapa demonstram que os alunos não tiveram dificuldade em analisar os dados, o que comprova a intuição destes em relação à estrutura da língua. Os alunos que não responderam ao box conclusivo observaram os dois critérios analisados ao longo das respostas presentes nas demais questões da etapa, 
ou seja, 18 alunos observaram de maneira eficiente as relações sintáticas e semânticas que relacionam o sujeito ao predicado das orações. $\mathrm{O}$ fato de não terem respondido ao box conclusivo pode, portanto, ter acontecido por de falta de atenção. Notou-se que alguns alunos demonstraram mais atenção ao critério sintático, o que pode ter ocorrido por conta de aulas anteriores com relação ao assunto, nas quais a professora pode ter dado mais atenção a tal critério. Não se considera, no entanto, que tal fato negue a intuição dos alunos referente às questões semânticas que relacionam o sujeito ao predicado. Quanto aos alunos que apresentaram respostas incoerentes, acredita-se que isso se deva a não interpretação adequada dos enunciados. $\mathrm{O}$ aluno que não observou nenhum dos critérios estabelecidos, não se demonstrou como um dado relevante para o questionamento acerca da intuição dos alunos sobre a estrutura da língua. Ao todo, considera-se que, dos 30 alunos que responderam a etapa, 27 obtiveram o desempenho esperado.

- $\quad 2^{\mathbf{a}}$ etapa - Construção de critérios para as classificações:

19 alunos responderam corretamente a todas as questões presentes na etapa;

1 aluno demonstrou dar mais atenção ao critério semântico para a identificação do sujeito;

5 alunos demonstraram dar mais atenção ao critério sintático para a identificação do sujeito;

2 alunos apresentaram respostas incoerentes;

2 alunos não responderam ao box em que constam as conclusões acerca do conteúdo desenvolvido na etapa.

Os dados obtidos nessa etapa apontam que os alunos construíram um raciocínio crítico sobre as relações entre o sujeito e o predicado se utilizando dos conceitos apresentado na $1^{\text {a }}$ etapa, relações de concordância e valor semântico dos termos, o que também demonstra a consolidação da aprendizagem de tais conceitos. Acredita-se que o fato de alguns alunos não terem respondido ao box conclusivo possa ter se dado por falta de atenção, tendo em vista que esses alunos apresentaram respostas eficientes nas demais questões presentes na etapa. Às respostas incoerentes atribui-se a não compreensão dos enunciados. Quanto ao fato de alguns alunos ainda se aterem mais ao critério sintático, isso pode ser consequência da tradição do ensino de gramática normativa. De um modo geral, considera-se que os alunos apresentaram um bom desempenho na etapa, obtendo-se 27 respostas eficientes das 30 atividades analisadas. 
- $\quad 3^{\mathbf{a}}$ etapa - Construção das regras:

1 alunos respondeu de maneira correta todas as questões presentes na etapa;

19 alunos não reconhecem o pronome interrogativo como sujeito;

4 alunos não compreenderam os enunciados;

11 alunos confundem os complementos verbais com o sujeito da oração;

3 alunos apresentam dificuldade em classificar sujeitos não expressos;

4 alunos não reconhecem sujeito inexistente;

4 alunos consideram sujeito desinencial como sujeito expresso;

5 alunos confundem o plural com sujeito composto;

8 alunos confundem a construção sujeito + adjunto adnominal com sujeito composto;

7 alunos não responderam questão 2 completamente ou o fizeram de forma incoerente;

3 alunos não responderam ao box em que constam as conclusões acerca do conteúdo desenvolvido na etapa.

O que se observou nessa etapa é que o critério morfológico para a identificação do sujeito se faz essencial para os casos em que pronomes exercem tal função, em que se tem um termo no plural como sujeito e para os casos em que o núcleo do sujeito vem acompanhado com um adjunto. Os alunos apresentaram muitos erros com construções desses tipos, e a atividade acabou por se apresentar falha em não trabalhar de maneira eficiente o critério morfológico ao longo da resolução dos exercícios. Também foi observado que os alunos apresentam dificuldade com a classificação dos sujeitos não expressos, alguns tendem a classificar sujeitos desinenciais como sujeitos expressos, por ser possível sua identificação, e também tendem a considerar os complementos verbais como sujeitos da oração quando estas não possuem sujeito. No que diz respeito ao uso da pergunta "QUEM?" para auxiliar na identificação do sujeito, observou-se que ela acaba por confundir os alunos na classificação do sujeito desinencial, uma vez que eles conseguem responde-la e acabam por considerar tal tipo de sujeito com sujeito expresso, além de não favorecer a identificação do pronome exercendo a função de sujeito quando este não é um pronome pessoal do caso reto.

De um modo geral, essa etapa foi a que apresentou maiores problemas de realização. Por ser a etapa mais longa da atividade e conter alguns exercícios trabalhosos, muitos alunos não responderam completamente a etapa ou o fizeram de 
maneira aleatória, sem atentarem-se aos comandos. Viu-se a necessidade de reformulação dessa etapa, pois essa não se mostrou eficiente para trabalhar a classificação do sujeito. Faz-se necessário uma redistribuição das questões, além de um trabalho mais apurado com as questões morfológicas que envolvem a classificação do sujeito e com as orações em que tal função sintática não existe.

- $\quad 4^{a}$ etapa - Aplicação das regras formuladas a contextos diversificados:

5 alunos responderam corretamente a todas as questões presentes na atividade;

23 alunos não reconhecem o sujeito oracional;

4 alunos acreditam que o sujeito será sempre o primeiro elemento da oração;

2 alunos não responderam a questão de maneira satisfatória;

3 alunos não responderam o box em que constam as conclusões acerca do conteúdo desenvolvido na etapa.

Nessa etapa foram trabalhadas questões relacionadas à ordem dos termos da oração e ao reconhecimento do sujeito oracional. Com as respostas obtidas, foi possível observar que os alunos, de um modo geral, não apresentaram problemas com relação à ordem, pois o número de alunos que acreditam que o sujeito será sempre o primeiro termo da oração não é suficiente para comprovar a ineficácia do exercício. Tendo isso em vista, considera-se que os critérios apresentados nas etapas anteriores foram suficientes para que eles reconhecessem tal função sintática em diferentes posições na oração. No entanto, com relação ao sujeito oracional, obteve-se um número muito grande de erros na identificação deste, o que demonstra que a falha da atividade em não trabalhar o critério morfológico comprometeu o resultado dos alunos nessa etapa, uma vez que eles não reconheceram o valor substantivo da oração.

- $5^{\mathbf{a}}$ etapa - Avaliação com base na revisão de textos:

2 alunos conseguiram identificar todos os sujeitos dos verbos solicitados e realizar as devidas correções;

2 alunos não responderam a etapa;

9 alunos não responderam a questão 2;

24 alunos não reconheceram o sujeito oracional;

13 alunos não reconhecem o pronome demonstrativo na função de sujeito;

5 alunos associam a função de sujeito ao elemento mais próximo ao verbo;

2 alunos não recuperam sujeitos elípticos. 
Essa etapa demonstrou o progresso dos alunos com relação ao desenvolvimento do conteúdo e os reflexos da falha na elaboração dos exercícios. Com relação ao progresso dos estudantes, observou-se que grande parte foi capaz de identificar os sujeitos elípticos, o que demonstra que os alunos foram capazes de recuperar o sujeito a partir do predicador e não apenas associando a função sintática de sujeito ao termo que antecede o verbo. Com relação às falhas da atividade, essas foram claramente observadas no alto índice de erros no reconhecimento do sujeito oracional e dos pronomes demonstrativo e interrogativo exercendo a função de sujeito. Associam-se tais "erros" ao fato de não ter sido trabalhado de maneira eficiente o critério morfológico na identificação do sujeito. Além de uma questão relacionada à intuição de sujeito nulo/expletivo, perspectiva pela qual a não identificação do sujeito oracional não pode ser considerada erro, mas, sim, um resultado da metacognição trabalhada com os alunos ao longo da atividade. Apesar dos problemas apresentados na resolução das etapas anteriores, os alunos demonstraram um desempenho satisfatório na revisão textual.

- $\mathbf{6}^{\mathbf{a}}$ etapa - Sistematização do conteúdo:

12 alunos responderam corretamente as questões presentes na etapa;

7 alunos não responderam a etapa;

1 aluno não compreendeu a questão;

3 alunos não preencheram os critérios para a identificação no sujeito;

3 alunos confundiram concordância verbal e nominal com critério semântico e sintático;

2 alunos não identificaram o sujeito inexistente;

2 alunos não identificaram os tipos de sujeito.

Nessa etapa esperava-se que os alunos organizassem, dentro de um esquema proposto, os conceitos desenvolvidos ao longo da atividade. Com as respostas dos estudantes, foi possível observar que, dos 22 alunos que alcançaram respostas satisfatórias (foram desconsiderados nessa contagem aqueles que não responderam a etapa e o aluno que demonstrou não ter compreendido o enunciado), 18 foram capazes de identificar os tipos de sujeito, o que demonstra que a atividade atingiu resultados positivos nesse aspecto. Com relação aos alunos que não preencheram os critérios para a identificação do sujeito e àqueles que preencheram o espaço destinado a tais critérios com os termos referentes aos tipos de concordância, verbal e nominal, acredita-se que 
tais respostas possam ter se dado em decorrência de falta de atenção às etapas anteriores da atividade.

\subsubsection{Contraste das amostras obtidas nas turmas 1 e 2}

Nessa subseção foram analisadas em contraste as respostas alcançadas pelos alunos das turmas 1 e 2 nas etapas 5 e 6 da atividade. Os dados foram organizados em tabelas que correspondem às respostas obtidas em cada etapa e foram analisados quanto ao número de acertos. As atividades entregues sem resposta para as questões em análise não foram utilizadas para a composição dos dados.

As tabelas 1 e 2 se referem, respectivamente, à primeira e à segunda questão da etapa 5 e a tabela 3 se refere à etapa 6 . Cada tabela foi analisada separadamente a fim de identificar as habilidades dos alunos em reconhecimento do sujeito, revisão de texto e organização dos conceitos desenvolvidos.

- Analise dos dados coletados na Etapa 5 - questão 1:

Tabela 1

\begin{tabular}{lll} 
Verbos Analisados & $\begin{array}{l}\text { Turma } \mathbf{T} \\
(\mathbf{2 8} \text { amostras })\end{array}$ & $\begin{array}{l}\text { Turma } 2 \\
(\mathbf{2 5} \text { amostras })\end{array}$ \\
\hline Acaba & $100 \%$ de acerto & $92 \%$ de acerto \\
Acabam & $100 \%$ de acertos & $100 \%$ de acertos \\
Podem & $50 \%$ de acertos & $8 \%$ de acertos \\
Sentou & $100 \%$ de acertos & $100 \%$ de acertos \\
Disse & $78 \%$ de acertos & $52 \%$ de acertos \\
É & $89 \%$ de acertos & $88 \%$ de acertos. \\
Caía & $96 \%$ de acertos & $100 \%$ de acertos \\
Mudou & $100 \%$ de acertos & $92 \%$ de acertos
\end{tabular}




$\begin{array}{lll}\mathbf{E} & 18 \% \text { de acertos } & 4 \% \text { de acertos } \\ \text { Acaba } & 100 \% \text { de acerto } & 92 \% \text { de acerto }\end{array}$

A tabela acima corresponde a habilidade dos alunos de identificarem o sujeito da forma verbal selecionada no exercício e, como se pode observar, os alunos da Turma 1 apresentaram melhor desempenho na identificação dos sujeitos elípticos do que os alunos da Turma 2, estes tentem a associar o sujeito ao termo que antecede ao verbo, não se atendo ao argumento selecionado pelo predicador. Tal observação pode ser realizada com a análise do verbo "disse" na primeira coluna.

Os alunos da Turma 2 também demonstraram maior dificuldade em reconhecer o pronome demonstrativo "estes" como sujeito da forma verbal "podem", no entanto, esperava-se um melhor resultado dos alunos da Turma 1 nesse tipo de análise. O que se observa é que os alunos apresentam dificuldade em analisar termos anafóricos por não terem referência definida, o que se confirma com o alto índice de acertos nas duas turmas com relação aos predicadores que selecionam sujeitos do tipo "simples" explícitos.

No que diz respeito ao sujeito oracional, nenhuma das duas turmas obteve um resultado satisfatório, o que demonstra que ambos os materiais didáticos utilizados falharam nesse aspecto.

- Análise dos dados obtidos na Etapa 5 - questão 2:

Tabela 2

Verbos Analisados

\section{Turma 1}

(19 amostras)

\section{Esquecem}

Dá

Têm

Precisa

Acham

Morre

Está

Acho

$90 \%$ de acertos

$63 \%$ de acertos

$74 \%$ de acertos

$63 \%$ de acertos

$74 \%$ de acertos

$63 \%$ de acertos

$68 \%$ de acertos

$58 \%$ de acertos
Turma 2

(20 amostras)

$90 \%$ de acertos

$45 \%$ de acertos

$40 \%$ de acertos

$55 \%$ de acertos

90\% de acertos

$45 \%$ de acertos

$75 \%$ de acertos

$60 \%$ de acertos 


\begin{tabular}{lll} 
Nasce & $89 \%$ de acertos & $60 \%$ de acertos \\
\hline É & $68 \%$ de acertos & $85 \%$ de acertos \\
Podemos & $58 \%$ de acertos & $65 \%$ de acertos \\
Conhecem & $84 \%$ de acertos & $50 \%$ de acertos \\
Trabalha & $74 \%$ de acertos & $55 \%$ de acertos \\
Fazerem & $58 \%$ de acertos & $60 \%$ de acertos \\
Tenha & $58 \%$ de acertos & $45 \%$ de acertos \\
É & $5 \%$ de acertos & $0 \%$ de acertos
\end{tabular}

A tabela 2 nos mostra o desempenho dos alunos em reconhecer o sujeito das formas verbais solicitadas na questão e corrigir possíveis erros de concordância. Os dados acima expostos confirmam a dificuldade dos alunos da Turma 2, em relação a Turma 1, de reconhecer os sujeitos elípticos, o que acabou afetando o desempenho de tais alunos na revisão textual. Os alunos da Turma 2 conseguiram, em sua maioria, revisar os as construções nas quais verbo e sujeito estavam próximos e em ordem direta, mas apresentaram dificuldade em fazer as correções nos predicados que faziam referência a sujeitos mencionados anteriormente, como se pode observar nos números referentes aos verbos: dá, têm, precisa, morre e trabalha.

De acordo com a análise dos resultados, quanto mais distante estão sujeito e predicador dentro do texto, maior a dificuldade dos alunos em relacioná-los. Os alunos da Turma 2 tiveram uma tendência maior de associar o sujeito ao termo que antecede o verbo.

As duas turmas apresentaram dificuldade quanto à identificação do pronome interrogativo exercendo a função de sujeito, como se observa nos números referentes à segunda ocorrência do verbo "é" na tabela. Tal dificuldade reforça o que se constatou na tabela 1 com relação ao pronome demonstrativo "estes" exercendo a função de sujeito do predicador "podem". No entanto os alunos parecem ter mais dificuldade em analisar o pronome interrogativo, do que analisar o pronome demonstrativo. Quanto a essa constatação, podemos atribuir tal dificuldade ao fato de o pronome interrogativo, nos textos abordados, ter uma referência menos definida que a do pronome demonstrativo.

Observou-se também que os alunos da Turma 1 apresentaram um desempenho inferior aos alunos da Turma 2 no que diz respeito a identificação do sujeito desinencial, dados presentes nos números referentes aos verbos "acho" e "podemos". Credita-se esse 
baixo desempenho ao fato de não terem sido trabalhados de maneira satisfatória na atividade os aspectos relacionamos à morfologia na questão da identificação do sujeito.

- Análise dos dados obtidos na Etapa 6:

Tabela 3

Aspectos Analisados

Critérios para identificação do sujeito

Tipos de Sujeito
Turma 1

$70 \%$ de acertos

$82 \%$ de acertos

\section{Turma 2}

$0 \%$ de acertos

$88 \%$ de acertos

A tabela 3 mostra os resultados dos alunos no que diz respeito à sistematização do conteúdo estudado. Como se observa, os dois materiais didáticos, tanto a atividade testada na Tuma 1, quanto o livro didático utilizado pela Turma 2, foram efetivos no que diz respeito à classificação do sujeito. Os alunos, de um modo geral, conseguiram assimilar a nomenclatura apresentada, no entanto como se revela nas tabelas anteriores, tal fato não garante o bom desempenho dos alunos quanto à identificação dos sujeitos quando presentes em produções em produções textuais e nem o desenvolvimento da habilidade dos estudantes de revisão textual. O que se pode inferir de tais dados é que a taxonomia pode requerer outro tipo de conhecimento independente da GU.

Outro fato que chama atenção é com relação ao reconhecimento dos critérios para a identificação do sujeito. Os alunos da Turma 2 não parecem ter sistematizado os fatores que relacionam o sujeito ao predicado, critérios semântico e sintático, enquanto que os alunos da Turma 1 assimilaram e recuperaram essa informação com maior facilidade. O que se observa é que o livro didático não trabalha e maneira clara tais critérios, ou os associa a outros temas, como a concordância.

\subsection{Considerações Parciais}

A partir da análise das respostas dos alunos da Turma 1 ao exercício e do contraste entre as respostas dos alunos das Turmas 1 e 2, foi possível perceber que a abordagem do aprendizado pela descoberta se revela um caminho promissor no ensino de língua materna. 
As respostas ao exercício aplicado à Turma 1 mostraram uma nítida associação, por parte dos alunos, do conteúdo estudado ao conhecimento de mundo que possuem. Pode-se notar, ao longo da atividade, que os alunos passaram a utilizar os conceitos apresentados nas etapas anteriores para responder aos exercícios seguintes. A evolução das respostas, com relação à complexidade e ao uso das terminologias, revelou a evolução do raciocínio destes nas análises. Apesar disso, ainda percebe-se que alguns alunos não exploram todas as possibilidades de combinações estruturais, apresentam problemas de leitura e compreensão dos enunciados, o que resulta em respostas incoerentes no decorrer das etapas, não dedicam a atenção necessária para a resolução das questões e não conseguem articular de maneira coerente as informações oferecidas ao longo do exercício.

Com relação ao contrates das respostas entre os alunos das Turmas 1 e 2, percebeu-se que os alunos da Turma um se ativeram mais às correspondências semânticas e sintáticas que subjazem a relação sujeito e predicado. Tal atenção foi constatada principalmente com relação ao reconhecimento dos sujeitos implícitos, no qual os alunos da Turma 2 tenderam a relacionar o sujeito do predicador ao termo que o antecede ao invés de recuperá-lo na estrutura textual como fizeram os alunos da Turma 1. No entanto, ambas as turmas demonstraram dificuldade em identificar o sujeito quando pronomes interrogativos exerciam tal função, orações em sujeito e o sujeito oracional.

\section{Considerações Finais}

Esse trabalho teve o objetivo de demonstrar de que forma os princípios relacionados à teoria gerativista aliados a metodologias metacognitivas podem contribuir para tornar o ensino de gramática mais eficaz na educação básica. Para tanto, foram abordados trabalhos que relacionam os pressupostos gerativistas ao ensino de gramática, foram analisados estudos sobre metodologias de ensino que defendem a perspectiva da aprendizagem ativa e o design instrucional e foi desenvolvida e testada uma atividade, formulada com base nesses pressupostos, com o objetivo de desenvolver a consciência linguística em sala de aula. 
No capítulo 1, baseado nos estudos de Silva (2013), foram estabelecidas relações entre os princípios gerativistas e o ensino de gramática, assim as contribuições dessa abordagem teórica para o desenvolvimento de metodologias de ensino. Para isso foram analisadas as obras de Lobato (2013), Kato (2005), Pilati; Naves; Vicente \& Salles (2011), Vicente \& Pilati (2012) e Silva (2013). Tais análises mostraram a atual preocupação dos estudos gerativistas com as questões relacionadas ao "ensino" de língua materna

No capítulo 2, foram apresentadas pesquisas que se dedicam ao estudo do desenvolvimento da aprendizagem, à elaboração de metodologias de ensino e abordagens adotadas para o ensino de língua portuguesa no Brasil e em Portugal. Nesse capítulo, foram analisadas as obras Como as pessoas aprendem: cérebro, mente e escola (2010), Richards \& Rodgers (2001), Fink (2003), os Parâmetros Curriculares Nacionais (1997) e o Guião de Implementação do Programa de Português do Ensino Básico (2011).

Ao longo das análises realizadas, observou-se a importância que as descobertas acerca da construção do conhecimento tiveram para a reelaboração das práticas pedagógicas aplicadas ao ensino de línguas. O conhecimento prévio estabeleceu-se como o principal ponto de partida para a aprendizagem de novos conteúdos e, também, para as metodologias que visam à aprendizagem pela descoberta. Viu-se que o conhecimento passa a ser considerado como Conhecimento Utilizável, e o desenvolvimento da metacognição passa a ser um dos principais objetivos das práticas pedagógicas. Além disso, observou-se que as metodologias de ensino devem ser elaboradas de maneira sistematizada com vistas a seguir $\mathrm{m}$ arranjo hierárquico que combina Abordagem, Método e Técnica dentro de um design instrucional que norteia os objetivos do ensino e combina diferentes metodologias.

Com relação às diretrizes do ensino de Língua Portuguesa adotadas no Brasil e em Portugal, observou-se que o documento de orientação para o "ensino" de língua portuguesa implementado em Portugal se mostra muito mais bem sistematizado, organizado e prático, do que o implementado no Brasil. A abordagem de ensino que o Brasil visa a adotar ainda carece de um documento que operacionalize as diretrizes apontadas pelos PCNs.

No capítulo 3, foi apresentada a atividade elaborada com base na perspectiva do ensino pela descoberta e do desenvolvimento da consciência linguística. A atividade baseou-se no desenvolvimento do conhecimento explícito dos alunos seguindo os 
seguintes princípios: a) investir em descrições mais adequadas da gramática do português; b) tomar consciência do grau de desenvolvimento linguístico dos alunos e dos aspectos da língua que não decorrem de uma aquisição espontânea; c) investir num ensino da língua que capitaliza as regularidades e d) orientar o estudo da gramática em dimensões para além da mera correção do erro (CF. COSTA, 2010). Para isso foram apresentados, primeiramente, os conceitos de sujeito e predicado utilizados na elaboração da atividade, conforme Duarte (2007) e Raposo (2014). Em seguida, foram explicadas as concepções teóricas que serviram de base para a elaboração de cada etapa da atividade, assim como o objetivo de cada etapa. Por fim, foram analisados os resultados obtidos com a aplicação do exercício em contraste com os resultados apresentados pela utilização do livro didático.

A partir da análise das respostas dos alunos da Turma 1 ao exercício e do contraste entre as respostas dos alunos das Turmas 1 e 2, percebeu-se que a abordagem do aprendizado pela descoberta se revela um caminho promissor no ensino de língua materna. Os alunos da Turma 1 demonstraram uma nítida associação do conteúdo estudado ao conhecimento de mundo que possuem. Além de ter sido possível notar a evolução das respostas dos alunos, com relação à complexidade e ao uso das terminologias e o desenvolvimento do raciocínio destes diante das análises.

Com relação ao contrates das respostas entre os alunos das Turmas 1 e 2, percebeu-se que os alunos da Turma 1 se ativeram mais às correspondências semânticas e sintáticas que subjazem a relação sujeito e predicado, uma vez que os alunos da Turma 2 tenderam a relacionar o sujeito do predicador ao termo que o antecede ao invés de recuperá-lo na estrutura textual como fizeram os alunos da Turma 1. No entanto, ambas as turmas demonstraram dificuldade em identificar o sujeito quando pronomes interrogativos, orações em sujeito e o sujeito oracional exerciam tal função.

A aplicação da atividade aos alunos do $7^{\circ}$ ano mostrou resultados muito satisfatórios. A atividade também se mostrou capaz de recuperar os alunos que haviam apresentado dificuldade na aprendizagem do conteúdo abordado, no entanto o comando de algumas questões não foi compreendido por todos os alunos, um ponto importante a ser aprimorado no exercício.

De um modo geral, o material didático desenvolvido demonstrou resultados positivos. No entanto, o uso de uma metodologia inovadora para o ensino de gramática, é algo bastante complexo, que requer investigações científicas mais profundas e testes mais complexos para avaliar sua efetividade. Faz-se necessário continuar 
desenvolvendo a pesquisa sobre tal tema e investigar outras questões relacionadas tanto às questões teóricas que envolvem o aprendizado linguístico e à faculdade da linguagem como continuar testando a efetividade de novas metodologias relacionadas à língua portuguesa e questões linguísticas e gramaticais na educação básica. 


\section{Referências Bibliográficas}

BRASIL. Secretaria de Educação Fundamental. Parâmetros curriculares nacionais: língua portuguesa. Brasília. 1997.

CHOMSKY, et alli. Novas perspectivas linguísticas. Petrópolis: Vozes, 1970.

Linguagem e pensamento. Petrópolis: Vozes, 1971.

Regras e representações; a inteligência humana e seu produto. Rio de Janeiro:

Zahar, 1981.

.Novos horizontes no estudo da linguagem e da mente. São Paulo: UNESP, 2005.

COMITÊ DE DESENVOLVIMENTO da Ciência e da Aprendizagem. Como as pessoas Aprendem: cérebro, mente, experiências e escola. Edição Brasileira: São Paulo: Senac, 2007.

COSTA, João et al. Guião de Implementação do Programas de Português do Ensino Básico: Conhecimento Explícito de Língua. Lisboa: Ministério da Educação/DireçãoGeral de Inovação e de Desenvolvimento Curricular, 2011.

DUARTE, Maria E. L.. "Termos da Oração". In: Vieira, S. \& Brandão, S. Ensino de Gramática: descrição e uso. São Paulo: Contexto. 2007. 185-204.

FINK, L. Dee. Creating Significant Learning Experiences: an integrated approach to designing college courses. 2003.

FRANCHI, Carlos et al. Mas o que é mesmo 'gramática'?. São Paulo: Parábola, 2006.

GAUTHIER \& TARDIF (org.). A pedagogia: Teorias e práticas da Antiguidade aos nossos dias. Petrópolis, RJ: Vozes, 2010.

KATO, Mary A. “A Gramática do Letrado: Questões para a Teoria Gramatical”. In.: M. A. Marques, E. Koller, J. Teixeira \& A. S. Lemos (orgs). Ciências da Linguagem: trinta anos de investigação e ensino. Braga, CEHUM (U. do Minho), 2005: 131-145.

LOBATO, Lúcia Maria P. $O$ que o professor de ensino básico deve saber de linguística? Apresentação na SPBC (manuscrito). Fortaleza, 2003.

LUFT, Celso Pedro. Língua e Liberdade. São Paulo: Ática. 6ª ed. 1993.

MARCHUSCHI, Luiz Antônio. Da fala para a escrita: atividades de retextualização. $2^{\mathrm{a}}$ ed. São Paulo: Cortez, 2001.

MATEUS, Maria Helena Mira et al. Gramática da Língua Portuguesa. Portugal: Caminho, 2003.

MURRIE, Zuleika de Felice (Org.). O Ensino de português. São Paulo: Contexto, 1992. 
NEVES, Maria Helena M. Gramática na escola. $8^{a}$ ed. São Paulo: Contexto, 2007.

PERINI, Mário A. Para uma nova gramática do português. São Paulo: Ática, 1986. . Gramática descritiva do português. São Paulo: Ática, 2007.

PILATI, Eloisa; NAVES, Rozana Reigota; VICENTE, Helena Guerra; SALLES, Heloisa. "Educação linguística e ensino de gramática na educação básica". In. Linguagem \& Ensino, v.14, n.2, p.395-425, jul./dez. 2011.

PILATI, Eloisa. "Laboratório de Ensino de Gramática: Questões, Desafios e Perspectivas". In. O que a distância revela: reflexões de professores e estudantes do Curso de Letras - EaD-UnB / Josênia Antunes Vieira, Francisca Cordelia Oliveira da Silva, organizadoreas - Brasília: Movimento, p. 48 - 67, 2014.

RAPOSO, Eduardo B. P. et al. Gramática do Português. Fundação Calouste Gulbenkian, 2013.

RICHARD, Hudson. "Why education needs linguistics (and vice versa)". Journal of Lingustics, v. 40, p. 105 - 130, 2004.

RICHARDS, Jack C. \& RODGERS, Theodore S. Approaches and methods in Language Teaching. Cambridge University Press, 2001.

SALLES, Heloisa M. M. Lima. A língua portuguesa na escola: por uma educação científica. Brasília: SBPC, 2005.

SILVA, Junia Lorenna da. Contribuições dos Pressupostos Gerativistas para a Educação em Língua Materna. Universidade de Brasília, 2013.

TRAVAGLIA, Luiz Carlos. Gramática: ensino plural, São Paulo: Cortez, 2007.

VANPATTEN, Bill. From input to output: a teacher's guide to second language acquisition. United States of America, 2003.

VICENTE, Helena. G; PILATI, Eloísa. "Teoria Gerativa e "ensino" de gramática: uma releitura dos Parâmetros Curriculares Nacionais". In: Verbum - Cadernos de PósGraduação, São Paulo, n. 2, p. 4-14, jul./dez. 2012. Disponível em: http://revistas.pucsp.br/index.php/verbum/article/view/12793/9279

XAVIER, Lola Geraldes. "Ensinar Gramática pela Abordagem Ativa de Descoberta". In: Exedra, p. 468 - 478, dezembro, 2012. 